Article

\title{
Social Insurance Accounting for a Notional Defined Contribution Scheme Combining Retirement and Long-Term Care Benefits
}

\author{
Carlos Vidal-Meliá ${ }^{1,2,3, *(\mathbb{D})}$, Manuel Ventura-Marco ${ }^{1}$ (i) and \\ Juan Manuel Pérez-Salamero González ${ }^{1}$ (D) \\ 1 Department of Financial Economics and Actuarial Science, University of Valencia, 46010 Valencia, Spain; \\ manuel.ventura@uv.es (M.V.-M.); juan.perez-salamero@uv.es (J.M.P.-S.G.) \\ 2 Instituto Complutense de Análisis Económico (ICAE), Complutense University of Madrid, \\ 28040 Madrid, Spain \\ 3 Centre of Excellence in Population Ageing Research (CEPAR), UNSW, Sydney, NSW 2052, Australia \\ * Correspondence: carlos.vidal@uv.es; Tel.: +34-963-828-383
}

Received: 12 June 2018; Accepted: 7 August 2018; Published: 9 August 2018

\begin{abstract}
This paper develops a social insurance accounting model for a notional defined contribution (NDC) scheme combining retirement and long-term care (LTC) contingencies. The procedure relies on standard double-entry bookkeeping and enables us to compile a "Swedish" type actuarial balance sheet (ABS) following a framework equivalent to an open group approach. This methodology is suitable for reporting the system's solvency status and can show periodical changes in the system's financial position by means of an income statement. The information underpinning the actuarial valuation is based on events and transactions that are verifiable at the valuation date, without considering expected future trends. The paper also contains an illustrative example to make it easier for policymakers to understand the main advantages and difficulties of our proposal. The policy conclusions stress the need to properly report social insurance benefits to enhance transparency and sustainability and to improve decision-making because it is in the public interest to do so.
\end{abstract}

Keywords: life care annuities; long-term care insurance; notional defined contribution; pay-as-you-go; pension accounting; retirement; social security; sustainability

\section{Introduction}

Accounting is a necessary requirement for any business, organization or entity, including public and private pension schemes, to enable it to keep track of its resources [1]. A public pension system should not be an exception, irrespective of the method used to finance the benefits. Financial reporting is one of the foundations of good management. High-quality financial reports are essential to ensure that decisions are based on the most up-to-date and accurate understanding of an organization's financial position [2].

Most government-managed pension schemes around the world are based on the pay-as-you-go (PAYG) financing method, whereby current contributions finance current benefits. Financial reporting of PAYG pension schemes based exclusively on cash accounting is not a suitable framework for accounting the assets and liabilities allocated to pay for the scheduled benefits. Reporting should be based mainly on the accrual accounting principle, which recognizes transactions or events when they occur, regardless of when the cash is paid or received. Indeed, in many countries, the financial reporting of public pensions has at best been very poor, with public budgets only giving information about the expected annual income from contributions and disbursement on pensions, and accounting standards 
being used only "haphazardly". According to Hoogervorst [3], "Around the world, governments give very incomplete information about the huge, unfunded social security liabilities they have incurred. Many executives in the private sector would end up in jail if they reported like Ministers of Finance, and rightly so."

There are, however, some countries that serve as examples of good financial reporting as regards public pensions. These include Canada [4-6], the US [7], Japan [8], the UK [9] and Sweden [10].

There has been long-standing interest in improving the measurement and recognition of unfunded public pension entitlements [11]. In fact, it became compulsory in 2017 for European Union (EU) Member States to disclose unfunded pension liabilities for social security pension schemes in a supplementary table to the national accounts. This obligation comes from the updating of the international System of National Accounts [12], which has been adopted into the European System of National Accounts ESA 2010 [13].

The overall aim of this supplementary table is to present the opening and closing stocks of pension entitlements for all social insurance pension schemes, along with all transactions and other economic flows during the period that account for the difference between the opening and closing positions, thus systematically showing pension obligations for all these schemes and facilitating international comparability $[14,15]$. However, the record of accrued-to-date liabilities is not an appropriate indicator of the system's sustainability. It corresponds to the amount of resources that have to be set aside today in order to finance all the pension rights that have been earned up to a given year [16,17], and therefore captures only one side of a pension scheme's balance sheet.

From a Social Security Administration's point of view, a valuable instrument for reporting the system's financial status is the so-called actuarial balance (AB), as it explicitly records assets and liabilities. It can be said that the $A B$ supplies a positive incentive to improve the financial management and sustainability of PAYG systems by minimizing the traditional mismatch between the planning horizons of electors and politicians and those of the system itself. Moreover, the regular disclosure of pension data works against the "squared fiscal illusion", because the burden on future generations is made transparent and the backdoor shifting of this burden is made more difficult [18]. It is worth mentioning that the $\mathrm{AB}$ approach is not based on traditional budgetary principles that consider public finances as a whole. Instead, it deals with the financing of public pensions by taking into account only the specific sources of finance for the scheme.

As far as compiling an AB for PAYG systems is concerned, there are basically two options: what are known as the Swedish [10] and the US models [7]. The Swedish actuarial balance sheet (ABS) can be described as a financial statement listing the pension system's obligations to contributors and pensioners at a particular date, with the amounts of the various assets (financial and mainly through contributions) that underwrite those commitments. It aims to provide a solvency indicator by measuring the value of the commitments to contributors and pensioners taken on by the system, rather than by considering its market value.

The US AB is a measure of the program's financial status for its entire 75-year valuation period. Essentially, it shows the difference between the income and the cost of the program expressed as a percentage of taxable payrolls over the valuation period [19]. This single number summarizes the adequacy of program financing for the period. Other standard measures are also reported on the US $\mathrm{AB}$, such as annual balance ratios, the cross-over date (when non-interest receipts begin falling short of program outlays), the date of trust-fund exhaustion, and other summarized actuarial balances calculated over truncated horizons of 25 and 50 years or even under perpetuity and stochastic calculations. In contrast to the US AB model, in the Swedish ABS, the assets and liabilities of the pension system are valued mainly on the basis of events and transactions that are verifiable at the time of valuation with no need for explicit projections.

The present paper deals with the development of a social insurance accounting model for a notional defined contribution (NDC) scheme combining retirement and long-term care (LTC) contingencies. It presents and discusses the main entries on a Swedish-type ABS specifically designed for NDC schemes. The Swedish ABS relies on standard double-entry bookkeeping and gives priority 
to the measurement of assets and liabilities as they stand at one particular point in time, which means that it is suitable for reporting the system's solvency status. Such a framework can also show periodic changes in the system's financial position by means of an income statement (also known as the gain and loss account).

The ABS is compiled using a methodology equivalent to an open group approach, although at first sight it might look like the closed group approach widely applied in fully-funded systems. The open group approach is based on the assumption that a plan is ongoing so that future new entrants can be included in the valuations. This assumption is similar to the "going concern" concept in accounting, which implies that the business will continue its operations in the future and will not liquidate or be forced to discontinue operations for any reason.

This paper builds on previous work carried out in the field of actuarial balances [11,20-33]. All of these have dealt with the Swedish-type ABS, which has been compiled for various countries including Sweden [10,24,27,28], Spain [24,31], Japan [21], Canada [6,30], New Zealand [25], Germany [33] and Switzerland [11].

As we show below, the Swedish-type ABS model is based on two essential concepts that make the balance sheet possible: the system's expected average turnover duration (TD) and the contribution asset (CA). These concepts initially appear in connection with NDCs, the general outline of which can be found in Settergren [20], and in Settergren and Mikula [22]. They are both modeled in continuous time and thus provide theoretical support.

The search for valid expressions to apply to defined benefit (DB) PAYG systems began with the paper by Boado-Penas et al. [24], which was the first to estimate the actuarial balance of the Spanish contributory pension system for the old-age contingency on the basis of official data. This line of research was continued by Vidal-Meliá [32], who in addition linked both types of actuarial balance. The paper by Vidal-Meliá and Boado-Penas [29] obtained the analytical properties of the CA and confirmed its soundness as a measurement for the assets of a PAYG scheme. However, all papers cited limit themselves to the retirement contingency. With the aim of making a comparison with the official actuarial valuation report on the Canadian Pension Plan (CPP), OSFIC [6] and Billig and Ménard [30] made a practical adaptation of the methodology used to compile the Swedish balance sheet. They drew up a modified ABS for the CPP that included retirement pensions, disability and survivor benefits. However, the theoretical basis for carrying out the adaptation was not developed in their papers. Finally, the paper by Ventura-Marco and Vidal-Meliá [31] developed a theoretical basis for compiling a Swedish ABS for a DB PAYG scheme with retirement and disability benefits.

Our paper also relies on research into NDC schemes, its starting point being the papers by TSPS [10], Pérez-Salamero González et al. [34], and Vidal-Meliá et al. [35]. Pérez-Salamero González et al. [34] developed a Swedish-type ABS for an NDC scheme with disability and minimum pension benefits. The most recent annual report of the Swedish pension system [10] presents its financial status and income statement along with a description of the accounting principles used for valuing the system's assets and liabilities. Finally, the paper by Vidal-Meliá et al. [35] explored the idea of using an NDC scheme embedded in the public pension system to provide retirement and graded cash-for-care (CFC) benefits in order to help pensioners cope with the cost of LTC.

As far as we know, this paper contributes to filling a gap in the literature because it deals with a social accounting model that has so far not been developed for the case of a combined pension system covering retirement and LTC. Our proposal has practical implications, which could be interesting not only for countries with an already-functioning NDC system but also for social security actuaries, public finance economists, pension policy experts and policy-makers.

The structure of the paper is as follows. After the Introduction, Section 2 develops a social insurance accounting model for an NDC scheme combining retirement and LTC contingencies. Once the model's background has been explained, for clarity's sake we divide this section into three subsections. The first describes the model's main accounting principles and the assumptions used for valuation, the second develops a Swedish-type ABS for an NDC scheme combining retirement 
and LTC contingencies, and finally the third presents the income statement. Section 3 provides a numerical illustration, compiling an ABS based on the proposed NDC scheme. This section is split into two different parts. The first shows the ABS under the mature state assumption, while the second illustrates annual changes in the system's financial position by means of an income statement for an already-functioning system. The paper ends with the concluding comments, Appendix A and a list of abbreviations.

\section{The Model}

This section presents and discusses a social insurance accounting model for an NDC scheme combining retirement and LTC contingencies. The link between old-age income and long-term care policy has long been acknowledged in the literature [36-40], and it is well established that retirement and LTC planning are considered to go hand-in-hand [41-46].

The underlying framework supporting this accounting model relies on the proposal made by Vidal-Meliá et al. [35], who explored an NDC approach aimed at using CFC benefits to help pensioners to cope with the cost of LTC if they become dependent. The purpose of their proposal is to provide partial coverage of the LTC costs incurred by retirement pensioners. The provision of LTC in this case would be considered one of the pillars of multi-pillar public schemes. The model can be used for life care annuities (LCAs) or enhanced pension annuities (EPAs).

The way LTC is treated in their proposal has several advantages. Briefly, it makes it easier to integrate both contingencies into an NDC framework, it raises awareness of LTC needs and, at least on paper, it is financially sound and sustainable over time. Furthermore, it does not raise the contribution rate for workers (EPA option), it extends LTC coverage, it introduces redistribution in a very transparent way and it allows the sponsor (the state) to more effectively take into account trends in disability, longevity and other sources of risk when "pricing" benefits.

The main elements underpinning their proposal are the NDC, LTC, CFC and LCA (EPA). For the sake of completeness (and clarity), it is worth giving a brief definition of each.

An NDC pension scheme is a PAYG pension plan that mimics a funded defined contribution plan [47-49]. An NDC scheme works in much the same way as ordinary savings in the bank. Contributors continue to pay for today's pensioners but their contributions are also credited to notional accounts that get a (notional) rate of return tied to wage growth or overall economic growth, rather than providing a return on specific financial assets. When they retire, the amount of their individual pension benefit is based on the notional capital they have each accumulated, which is converted into an annuity in line with a formula based on life expectancy at their retirement age. The fundamental logic of NDC schemes is that every monetary unit of a liability has to have a financial counterpart, i.e., contributions on earnings for NDC rights and contributions from the government to cover non-contributory rights (NCRs). This is a principle that, when fulfilled, ceteris paribus, assures long-term financial sustainability. The proposal made by Vidal-Meliá et al. [35] is a logical extension of NDC principles to include LTC coverage. This system mimics the LTC coverage provided by a LCA or EPA in an NDC framework.

Long-term care (LTC) includes the health and social support services provided to those with chronic illness or physical or mental disability to help them achieve and maintain an optimal level of functioning [50-54].

The need for LTC typically arises as part of the normal ageing process, but can also be due to an injury or illness such as a stroke, or a cognitive impairment such as dementia or Alzheimer's disease. The degree of LTC need is often assessed according to a scale measuring the basic activities of daily living (ADL) and/or the instrumental activities of daily living (IADL). ADLs are basic self-care tasks, akin to the skills that people usually learn in early childhood, while IADLs are the complex skills needed to successfully live independently.

Whether an individual will need LTC and if so for how long is uncertain. Consequently, it is important to understand the LTC risks. It is equally important to individuals (and families) who are 
planning for retirement and are uncertain about their need for LTC. As a contributory contingency, it has been provided in the German contributory pension system since the mid-1990s. Other OECD countries with public contributory LTC arrangements include Japan, Korea, the Netherlands and Luxembourg.

To deal with an increase in pensioner care needs, the proposal uses a cash-for-care benefit (CFC), of which there are many with various names and forms $[55,56]$. These cash programs aim to give households some choice in care decisions, thereby fostering and supporting family care, developing care markets and containing costs.

Finally, but importantly, a life care annuity (LCA) is a lifetime annuity in which the LTC benefit is defined in terms of an uplift with respect to the basic amount. In return for the payment of a contribution collected over time, the LCA provides a stream of fixed-income payments for the lifetime of the annuitant (pensioner). It also provides an extra stream of payments if the annuitant requires LTC. An LCA with degree-related benefits means that the amount paid depends on the annuitant's degree of disability. An enhanced pension annuity (EPA) is an LCA in which the uplifts are financed by a reduction —with respect to the basic pension—in the benefit paid while the pensioner is healthy [57-62].

Because the model's technicalities and assumptions are too numerous to detail in full here, we limit ourselves to summarizing those that are most relevant to this analysis.

Affiliates contribute to both retirement and LTC contingencies. The LTC need is linked to retirement ages. There is a defined contribution rate (fixed over time), $\theta_{a}$, to cover both contingencies. There are $n$ levels of dependence, with Level 1 being the least severe and level $n$ the most. Becoming an LTC recipient means that the amount of retirement pension is automatically increased by a certain percentage, $\xi$, to help pay for care services, i.e., those dependent on care obtain additional cash to hire the required services as they see fit.

The model can use life care annuities (LCAs) or enhanced pension annuities (EPAs).

With LCAs, the LTC benefit (in the form of CFC) is defined in terms of an uplift with respect to the basic pension, $b$, which is paid out from retirement onwards and replaced by the LTC annuity benefit, $b \cdot\left(1+\xi_{r j}\right), j \in\{1,2, \cdots, n\}$, in the case of a particular level of LTC claim. An active pensioner is denoted by $r$. The uplifts can be financed over the whole accumulation period by contributions higher than those needed for entitlement to retirement benefit $b$.

The EPA is an LCA in which the uplifts are financed by a reduction-with respect to basic retirement benefit $b$-in the benefit paid while the pensioner is healthy. Thus, the reduced benefit, $b^{h}$, is paid out as long as the retiree is healthy, and the uplifted benefit, $b^{h} \cdot\left(1+\xi_{r j}\right)$, will be paid in the case of an LTC claim. Logically, $b^{h}<b<b \cdot\left(1+\xi_{r j}\right)$.

The system provides a minimum pension depending on individual health status, with the amount being related to the average wage. The age giving entitlement to retirement pension, $x_{e}+A$, is fixed. We also assume that participants' lives last $\omega-x_{e}$ periods, where $\omega$ is the maximum lifespan and $x_{e}$ is the earliest age of entry into the system.

Although an NDC scheme provides benefit for everyone who works and contributes to it, it will not necessarily provide everyone with a benefit that gives sufficient income for them to live on. It has long been recognized that NDC schemes should be supplemented with a minimum pension benefit (MPB) [63-66]. The introduction of an MPB is a way of preserving the social sustainability of the scheme as well as the adequacy of the pension.

In short, the main way in which this proposal differs from a pure NDC scheme is that, if the amount of the initial retirement pension (including a graded LTC benefit) is below a minimum value, the amount is supplemented up to the minimum benefit. The minimum pension guarantee requires that the government pay an amount equivalent to the difference between the accumulated notional pension account at the time of retirement and the amount that would provide an annuity equivalent to the MPB.

As regards the supplementary amount for dependence, it is assumed that the ages for eligibility to receive benefits are to be found in age interval $\left[x_{e}+A+1, \omega\right]$. 
The contribution base changes (in positive or negative terms) at an annual rate of $g$ and the economically active population increases or decreases over time at an annual rate of $\gamma$, affecting all groups of contributors equally. Thus, the system's income from contributions (covered wage bill) also grows (decreases) at rate $G=(1+g) \cdot(1+\gamma)-1$.

The model includes the so-called "survivor dividend", which means the account balances of participants who do not survive to retirement are distributed as inheritance capital (gains) to the accounts of the surviving participants on a birth cohort basis [67-70].

The initial amount of the annuity depends on several elements, the most important being the pension balance accumulated at retirement age. However, there are others that also matter: the current mortality of the cohort in the year the contributor reaches retirement, the LTC incidence rates by age, the probabilities of moving to a worse state of dependence, the amount of the uplifted benefits, the current mortality of dependent persons, and a notional imputed future indexation rate, $\alpha$ (see Appendix A).

Now that the model's background has been given, for the sake of clarity, this section is divided into three subsections. The first describes the model's main accounting valuation principles and assumptions. The second develops the Swedish-type ABS for an NDC scheme combining both retirement and LTC contingencies. The third presents the income statement.

\subsection{Accounting Principles for the Valuation of Assets and Liabilities and Main Assumptions}

The Swedish ABS is an assessment of the plan's financial position at a specific point in time, and economic, financial and actuarial assumptions are primarily based on past experience and standard tables (mortality and disability). It could be said that the Swedish ABS approach artificially freezes the NDC scheme for a split second in the same way that a still from a film freezes the action. This snapshot is taken to determine the plan's liabilities and its solvency status. To a certain extent, this accounting procedure is in line with the "insurance approach" [71]. The information provided will only be relevant and faithfully representative when there is a clear link between the benefits paid by a social security scheme and the revenue that finances them. An NDC scheme meets this requirement.

Swedish accounting practice in NDC schemes [10] means that the assets and liabilities of the pension system are valued mainly on the basis of events and transactions that are verifiable at the time of valuation, with no need for explicit projections. The sponsor is not required to report a higher life expectancy today just because life expectancy is likely to be higher in the future. This is not due to any belief that life expectancy or other factors such as transition rates or the expected time spent as dependent will remain totally constant. Instead, the accounting is designed not to include changed conditions until those changes are reflected in the events and transactions on which the accounting is based. According to this principle, the main data should be updated on an annual basis.

The ABS is compiled using a methodology equivalent to the open group approach. This is based on the assumption that a plan is ongoing so that future new entrants can be included in the valuations. Such an approach explicitly accounts for sources of financing by considering the benefits and contributions of both current and future plan participants, or to put it another way, it includes future generations of contributors and beneficiaries who participate in the plan's cost and risk-sharing. In a closed group approach, only current participants are included, with no new entrants allowed.

The accounts liabilities under this method consist of the present value not only of benefits in payment and benefits expected to become payable to current participants, but also of benefits expected to become payable to new entrants. Correspondingly, the assets include the present value of expected future contributions made by or on account of current participants and new entrants. As mentioned above, this model can be considered as open group in any particular year $t$ because it takes new entrants into account and assumes that there will be contributions to meet the liabilities, but the valuation formulas consider only pensioners and contributors at the valuation date. This particular conception of open group is used from a dynamic perspective, since the model enables us to draw up the ABS at any date $t$ after the system reaches a mature state [31]. As we show below, estimating the 
value of the contribution flow (contribution asset) by multiplying it by the turnover duration $(T D)$ is equivalent to discounting an assumed perpetual constant flow of contributions by the inverse of the $T D$. This involves an open group approach with a perpetual time horizon.

Increasing the length of the projection period can be said to enhance the assessment of financial sustainability, although it also increases the uncertainty of the results. Our social insurance accounting method presents the system's financial position by comparing the accrued pension liability with the value of the contribution flow at a particular point in time, which is estimated without projections. Since projections are based on a large set of demographic, economic and behavioral assumptions, the exact value of pension liabilities and the income from contributions is highly uncertain, and this is how the uncertainty surrounding long-term economic, demographic and financial projections is avoided when using the Swedish method.

The discount rate assumption is the most influential actuarial input affecting both funding ratios and contribution requirements [72]. In line with the classic Swedish ABS [10], which basically aims to compute the value of the commitments to contributors and pensioners taken on by the system, rather than calculate how much the system would have to pay a third party if it was decided to contract out or transfer those commitments, the interest rate for discounting liabilities to pensioners is taken to be the growth rate of the covered wage bill $(G)$. Several papers have used a discount rate tied to wage growth or overall economic growth [11,22,24,31,32,34,73].

Our proposal includes a minimum pension benefit (MPB), so, depending on the solution adopted to cover its cost, the discount rate used for valuing the liabilities to pensioners caused by NCRs could be different from the growth rate of the covered wage bill. If the alternative were to record supplementary pension payments in the same accounting period or fiscal year in which the MPBs were granted, then the asset counterpart would be a buffer fund financed by general government revenues. Using a buffer fund has the advantage of forcing politicians to guarantee pension promises made in the shape of MPBs, and it also keeps the system in order. In this case, the interest rate for discounting the liabilities to pensioners could be the variation rate in the general tax base $(T)$. Public funds in the UK use a discount rate based on the expected long-term growth of GDP [74,75]. If instead the alternative chosen were to record a claim on the state budget and have the state make partial payments on this debt, the discount rate could be a riskless rate (government bonds). Brown and Pennacchi [76] argued that public pension funds should use lower discount rates than private pension funds because public plan benefits are virtually free of risk, since accrued benefits are usually backed by constitutional guarantees.

To simplify the analysis, the interest rate for discounting liabilities to pensioners (deriving from NDCs or NCRs) in this paper is considered to be the growth rate of the covered wage bill $(G)$.

\subsection{The Swedish-Type ABS for an NDC Scheme Combining Retirement and LTC Contingencies}

In this subsection, we develop the main entries for a Swedish-type ABS designed specifically for NDC schemes. The idea of presenting the financial status of an NDC pension system in terms of assets and liabilities was first introduced in the Swedish NDC system in 2001. Our proposal, as shown in Table 1, is a little more complex because two contingencies need to be disclosed and the commitments deriving from the NCRs also have to be explicitly accounted for. It should be noted that disability benefits, survivor benefits and guaranteed minimum pensions are excluded from the Swedish accounting because they are not part of the NDC system but are financed separately, basically using general tax revenue [10].

In this proposal, the ABS splits the system into two parts: the NDC part and the redistributive part, which includes the assets and liabilities originating from NCRs.

The right-hand side of Table 1 shows the liability to pensioners for LTC (Pen_(LTC)) and the liability to pensioners for retirement (Pen_(R)). In general terms, the liability to pensioners can be defined as the present value of the amount of all the benefits in payment stemming from contributory 
rights plus non-contributory rights at the valuation date of the balance sheet. In this scheme, there are two types of pensioners: for retirement and for LTC.

Table 1. The ABS for an NDC scheme combining retirement and LTC contingencies.

\begin{tabular}{|c|c|}
\hline ASSETS & LIABILITIES \\
\hline Contribution asset for retirement: CA_(R) & $\begin{array}{l}\text { Liability to contributors for retirement: Con_(R) } \\
\text { Liability to pensioners for retirement: Pen_(R) }\end{array}$ \\
\hline $\begin{array}{c}\text { Public contribution asset: PCA_(R) or buffer } \\
\text { fund for retirement: BF_(R) }\end{array}$ & $\begin{array}{l}\text { Liability to contributors for retirement: Con_(R) NCR } \\
\text { Liability to pensioners for retirement: Pen_(R) NCR }\end{array}$ \\
\hline Contribution asset for long-term care: CA_(LTC) & $\begin{array}{l}\text { Liability to contributors for LTC: Con_(LTC) } \\
\text { Liability to pensioners for LTC: Pen_(LTC) }\end{array}$ \\
\hline $\begin{array}{l}\text { Public contribution asset: PCA_(LTC) or buffer } \\
\text { fund for long-term care: BF_(LTC) }\end{array}$ & $\begin{array}{l}\text { Liability to contributors for LTC: Con_(LTC) NCR } \\
\text { Liability to pensioners for LTC: Pen_(LTC) NCR }\end{array}$ \\
\hline Accumulated deficit: Ad_(R + LTC) & Accumulated surplus: As_(R + LTC) \\
\hline Losses for the period: $\mathbf{L}_{-}(\mathbf{R}+\mathbf{L T C})$ & Gains for the period: G_(R + LTC) \\
\hline Total Assets: $\left(A_{t}^{S}\right)$ & Total Liabilities: $\left(V_{t}^{S}\right)$ \\
\hline
\end{tabular}

This side also includes the liability to contributors for LTC (Con_(LTC)) and the liability to contributors for retirement (Con_(R)). When referring to contributors, actuaries use the term "technical provisions for rights being acquired", which will be reported here as liabilities to contributors. In this particular NDC scheme, the liability to current contributors is considered to be the notional capital accumulated in the participants' accounts (formed by the contributions made by participants, plus the return deriving from the notional rate of interest credited to those accounts, plus the survivor dividend). However, what about the liabilities to contributors for NCRs (Con_(R) NCR and Con_(R) NCR)? To quantify these liabilities, there are two alternatives.

The first is in line with one of the main principles used for compiling this type of ABS: the pension system's liabilities are valued mainly on the basis of events and transactions that are verifiable at the time of valuation with no need for explicit projections. In accordance with this principle, the liability to contributors for retirement and LTC due to NCRs should be zero. This view of recognizing and measuring social benefits coincides with the latest point at which an obligating event may give rise to amounts being recognized in the financial statements [71]. Under this option, public sector entities should only recognize legal obligations in respect of social benefits. Until a legal obligation exists and the due date has arrived, a claim is unenforceable. A government can always avoid settling such an obligation, for example by modifying the eligibility criteria or amending legislation prior to this point.

The second involves going against the principle of not making explicit projections. The inclusion of an MPB implies valuing the accrued minimum benefit by means of the prospective and forecasting method (see details in Appendix A).

Finally, this side also contains the accumulated surplus (As_(R+ LTC)), the gains for the period $\left(\mathbf{G}_{-}(\mathbf{R}+\mathbf{L T C})\right)$ and the total liabilities $\left(V_{t}^{S}\right)$. The accumulated surplus is the pension system's "accumulated gain" or net worth, which is owned by the system's sponsor, in this case the state. As shown in Section 2.3, the annual gain is the difference between the change in the value of the assets and the actuarial liabilities.

On the assets side, we find the contribution asset for LTC (CA_(LTC)) and the contribution asset for retirement (CA_(R)). In PAYG systems, the contribution flow is considered to be the principal asset, and the double-entry bookkeeping of the Swedish ABS is based on this reasoning. The Swedish concept of the value of the contribution flow is expressed as the contribution asset, which can be understood as the maximum liabilities that would have existed on the last day of the accounting period if there were no changes in the age-related income distribution, age-related mortality and morbidity, the size of the contribution (tax) base, the structure of uplifts to help pensioners cope with LTC and the 
pension system's rules. This is because, in a balanced system, the difference between the liabilities and current assets is the present value of the future contributions of the NDC system, i.e., the system's contribution asset (taking into account zero financial assets).

Once the process for obtaining the system's turnover duration has been developed (see Appendix A), the contribution asset is simple to calculate. It is the product of the size of the flow per time unit, which in practice is a year, and the expected time between payment of contributions and receipt of pensions, which is known as the turnover duration $(T D)$.

In our model, the $T D$ for the system could be interpreted as the number of years expected to elapse before the committed liabilities with contributors and pensioners for retirement and LTC are completely renewed at the current contribution level. Each monetary unit enters the system as if it were paid by a contributor of $A_{C}$ years and remains within the contribution liability until retirement age is reached (pay-in). It is then received by a pensioner aged $A_{r}$ years.

To preserve the system's solvency, the asset counterpart for underwriting the liabilities caused by NCRs can appear as a special type of public contribution asset (PCA_(LTC)) and (PCA_(R)) or as a buffer fund $\left(\mathbf{B F}_{-}(\mathbf{L T C})\right)$ and $\left(\mathbf{B F}_{-}(\mathbf{R})\right)$ financed by general government revenues. The Japanese $\mathrm{AB}$ has included the amount by which the state subsidizes the pension system for many years [8]. Metzger [11], and Pérez-Salamero González et al. [34] also included state subsidies in several balance sheet frameworks.

We also find the accumulated deficit (Ad_ $(\mathbf{R}+\mathbf{L T C}))$ and the losses for the period $\left(\mathbf{L}_{-}(\mathbf{R}+\mathbf{L T C})\right)$ on this side. Finally, the total assets are $A_{t}^{S}$. The accumulation of losses in each period determines the value of the accumulated shortfall at the date of the ABS, and "losses in each period" represents the difference between the change in value of the liabilities and the change in value of the assets for the period. The loss is also identical to the increase in the accumulated deficit or the reduction in the accumulated surplus, depending on the situation.

The entries shown in Table 1 are detailed in Appendix A.

\subsection{The Income Statement: Exploring the Reasons for the Change in Financial Position}

The ABS and the income statement are interrelated financial statements. In fact, the net "gain" for a period can be computed without an income statement. The simplest way to determine any change in the system's net worth is by comparing the system's assets and liabilities in two consecutive periods, but computing changes in this way means that there will be a significant lack of detail.

Under a present value model, assets and liabilities are measured at present value at each reporting date. More importantly, changes in present value are reported in each period as income or expenses and are included on the income statement. It can be said that the income statement fully explains the reasons behind the changes in the system's solvency, and in our model the reasons are also detailed by type of benefit.

The proposed structure of the income statement is shown in Table 2, in which it is assumed for simplicity's sake that NCRs are totally guaranteed by the sponsor and that the system's administration costs are financed by general taxation. This gain and loss account follows the model published by the Swedish authorities, but some modifications need to be introduced to adapt it to the NDC model combining retirement and LTC. Unlike in the Swedish system, we consider that inheritance gains arising and distributed are perfectly matched within the year.

The formulas for computing the entries are shown in the Appendix A.

The left-hand side (or credit side) of Table 2 lists changes in assets, which need to be interpreted in the following way: a negative item $(-)$ decreases the asset and a positive item $(+)$ increases it, by the amount shown.

The annual change in the fund asset or buffer fund is the result of adding the income from contributions to the net return on funded capital and deducting the expenses on pensions. Pension contributions are used to pay retirees in the same year. In practice, all pension contributions are 
paid and distributed monthly to the reserve fund. The surpluses or deficits that arise when pension contributions are greater or smaller than pension disbursements are absorbed by the buffer fund.

Table 2. The income statement for an NDC scheme combining retirement and LTC contingencies.

\begin{tabular}{cc}
\hline FUND ASSETS (Changes) & LIABILITIES (Changes) \\
\hline Pension contributions & New pension credit \\
Pension disbursements & Pension disbursements \\
Net return on funded capital & Indexation \\
\hline CONTRIBUTION ASSET (Changes) & Value of change in life expectancy \\
\hline Value of change in contribution revenue & Value of change in biometric assumptions \\
\hline Value of change in turnover duration & NET GAIN/LOSS \\
\hline Total & Total \\
\hline
\end{tabular}

The change in net worth should not be confused with the annual cash deficit or surplus, which is the difference between contributions received and pensions paid. Finally, the net return on funded capital includes dividends on assets held by the fund and the effects of changes in asset prices. In most public pension funds, financial assets are valued at their market price on the last trading day of the year. The net return on funded capital can be positive or negative depending on the situation of the financial markets.

On the debit side, we see the changes in the contribution asset broken down into contribution revenue and turnover duration. The value of the change in contribution revenue is the monetary value in terms of how much more (or less) liability can be financed by a higher (or lower) level of contributions relative to the preceding year [27].

The value of the change in the $T D$ is a combined effect of a variety of causes, given that this measure synthesizes into a single number a great deal of information about the system's rules, the age distribution of the population, the age patterns of the labor supply and earnings, mortality and disability rates and the design structure of the uplifts (see Appendix A).

On the credit side, we find the changes in pension liabilities. The associated items need to be interpreted as follows: a negative item $(-)$ decreases the pension liability and a positive item $(+)$ increases it, by the amount shown.

New pension credits are accumulated in the notional accounts, and this accounting item is identical to income from contributions-equality between contributions paid and new pension credits is (or should be) a key feature of an NDC scheme. Because pension payments are an amortization of the pension liability, that liability is reduced by the amount of the expenditure on pensions. Obviously, the amount of the pension disbursements matches on both sides of the income statement.

Changes in pension liabilities due to the indexation of notional accounts and benefits in payment are also accounted for. The pension liability can be increased by the value of indexation as long as the yearly notional rate is positive. Under an adverse economic trend, if the annual notional rate were negative, the pension liability would be reduced.

The "value of change in life expectancy" entry is for the annual update of life expectancy. This item is coherent with the accounting principle of updating the main data on an annual basis. Increased life expectancy not only adds to the pension liability; it also changes the pension liability's structure (the time profile of payments) in a way that does not need to be fully financed in a PAYG pension system [27]. The net effect of increases in life expectancy in an NDC scheme is an increased pension liability minus the increased value of the contribution flow that results from a higher turnover duration $[13,22,31,77]$.

The "value of change in biometric assumptions" entry mainly refers to the LTC contingency. Changes in transition probabilities and unhealthy life expectancy have implications for the value of the liabilities to contributors for LTC (see Appendix A). The situation could vary dramatically from country 
to country. Three broad scenarios have been suggested in the specialized literature for the future course of mortality and morbidity in developed countries: compression, expansion and dynamic equilibrium.

Assuming a future compression of morbidity due to an expected general decrease in its incidence owing to, for example, healthier lifestyles, technological and medical advances or interventions in the primary and secondary prevention of diseases, we could see a reduction in LTC pension liability. Two countries in which this situation already applies are the US and Germany. Stallard [78] found a very substantial and highly statistically significant compression of morbidity for both males and females in the US over the period 1984-2004. Similarly, Kreft and Doblhammer [79], using administrative census data on all beneficiaries from the Statutory LTC Insurance 2001-2009, found compression of life years with severe care need for Germany.

Under the most pessimistic scenario, i.e., the expansion of morbidity, the LTC pension liability would increase year by year, given that the general survival progress and later-active (or even missing) improvements in sickness prevention and recovery lead to an increasing duration of morbidity and a higher prevalence of health limitations. To give some real examples of countries in which this situation applies, we could single out Brazil and Spain. Gonçalves et al. [80] concluded that the expansion of morbidity is an ongoing process in the elderly population of the city of São Paulo (Brazil), based on data for the period 2000-2010. For the case of Catalonia (Spain), Solé-Auró and Alcañiz [81] found an expansion of morbidity after analyzing data for the period 1994-2011.

Under a neutral scenario, which Manton [82] termed dynamic equilibrium, both length of life and healthy years of life increase in such a way that the proportion of healthy years of life to total length of life is constant. Therefore, the health status of a population does not change and we could see stability in LTC pension liability. Graham et al. [83] found that this scenario provides the best fit to evidence on changes in population health in New Zealand.

We should bear in mind that quantifying the value of change in biometric assumptions is no easy task, given that obtaining timely and accurate estimates of mortality, transition and incidence rates is highly complex for technical reasons [84-88]. In many countries, the lack of biometric data could make it impossible to obtain regular representative estimates of functional status transition rates.

On the credit side we could have included another item known as the "value of change in discount rate $(G)^{\prime \prime}$, but in line with the reference model this was ruled out. For the case of an already-functioning DB pension system, Ventura-Marco and Vidal-Meliá [31] discussed four options when choosing the value of $G$ for discounting pensions in payment. The most suitable option for an already-functioning NDC scheme would be to use an estimated value of $G$ based on the most recently observed data (the previous three or five years), which is in keeping with the principle that assets and liabilities are valued mainly on the basis of events and transactions that are verifiable at the time of valuation. In practice, the introduction of this item would increase the volatility of the system's results and could trigger (unnecessarily) the automatic balance mechanism (ABM), which is a set of predetermined measures established by law to be applied immediately as required according to an indicator that reflects the system's financial health [89-91]. Börsch-Supan [92] called these ABMs rational mechanisms and points out that they are transparent because it is clear how adjustments will be made and who will bear what costs when an adjustment occurs.

The introduction of the "value of change in discount rate" into the income statement could call for a different $\mathrm{ABM}$ with the inclusion of a no-action range for the balance ratio in order to avoid an excessive number of triggers. If the solvency indicator fell outside this range, the ABM could restore it to within the no-action range [93]. This problem and the design of the range of balancing actions clearly goes beyond the scope of this paper.

Finally, to balance the income statement, the net gain or loss for the year is accounted for on the liability side. A positive value, if the debit items exceed the credit items in value, indicates that the system has increased its net wealth, i.e., there are gains for the period. A negative value, if the credit items exceed the debit items in value, means that the net wealth has decreased, i.e., there are losses for the period. 


\section{Numerical Illustration}

This section shows the results obtained for a numerical example representative of the model developed above. It is divided into two parts. The first shows the ABS under the mature state assumption, while the second shows the annual changes in the system's financial position via the income statement for an already-functioning pure NDC pension system.

The numerical example is presented to make it easier for the reader to understand how the proposed model for financial reporting functions and what its main advantages and disadvantages are. However, it should be viewed simply as an illustration because it uses a standardized population by age and the proposed scheme is not yet in operation in any country.

\subsection{The Swedish ABS for an NDC Scheme Combining Retirement and LTC Contingencies}

Our starting point was the numerical example developed by Vidal-Meliá et al. [35] for retirement and LTC. The effect of introducing a minimum pension on the system's financial status was also analyzed.

The main assumptions, which have been made as simple but as realistic as possible, are listed below.

It was assumed that individuals can join the labor market from Age 16 onwards, that the credited contribution rate is constant and equal to $16 \%$, and that the fixed retirement age for all individuals is 65 .

A concave income profile typical of developed countries was assumed. We also assumed that the contribution bases $(g)$ grow at an annual cumulative rate of $1.6 \%$ and that the economically active population of all ages $(\gamma)$ grows at an annual rate of $1 \%$.

It was also assumed that the initial pension benefit remains constant over time in real terms, i.e., $\alpha=0$, using price indexation of benefits.

As far as the LTC contingency is concerned, the data used to perform this numerical example were obtained from the model developed by Robinson [84], which provides seven health states that differ according to three variables: the number of IADLs impaired, the number of ADLs impaired, and whether there is a cognitive impairment.

Table 3 gives detailed information about life expectancy in years at Age 65 and the percentage of total life expectancy likely to be spent in each of the health states. We see that healthy pensioners at Age 65 will average 4.17 years of ADL disability or cognitive impairment over the rest of their lives, i.e., $25.52 \%$ of their remaining life expectancy ( 16.35 years) is expected to be in some state of dependence.

We need to remember that the biometric data used for the numerical example have a strong effect on the main values that make up the system's equilibrium. To give a couple of examples, data obtained from [94] for the US indicate that the amount of life expectancy likely to be spent in states of dependence will average 3.22 years, i.e., $21.11 \%$ of remaining life expectancy (15.26 years at Age 65). If we use data from $[85,86]$ for Australia, the figures would be different: for pensioners at Age 65, the percentage of life expectancy likely to be spent in states of dependence would average 8.17 years, i.e., $42.99 \%$ of remaining life expectancy (18.99 years).

Table 3 also shows that the expected number of years allocated to the possible range of health states depends on the starting status by age. For pensioners in state $d_{4}$ (the individual has three or more impaired ADLs but no cognitive impairment), estimated life expectancy is only 4.81 years, and it is expected that $24.15 \%$ of their remaining life will be spent in a worse state of dependence $\left(d_{5}\right.$ and $\left.d_{6}\right)$. 
Table 3. Life expectancy in years at Age 65 and percentage of life expectancy likely to be spent in each of the health states.

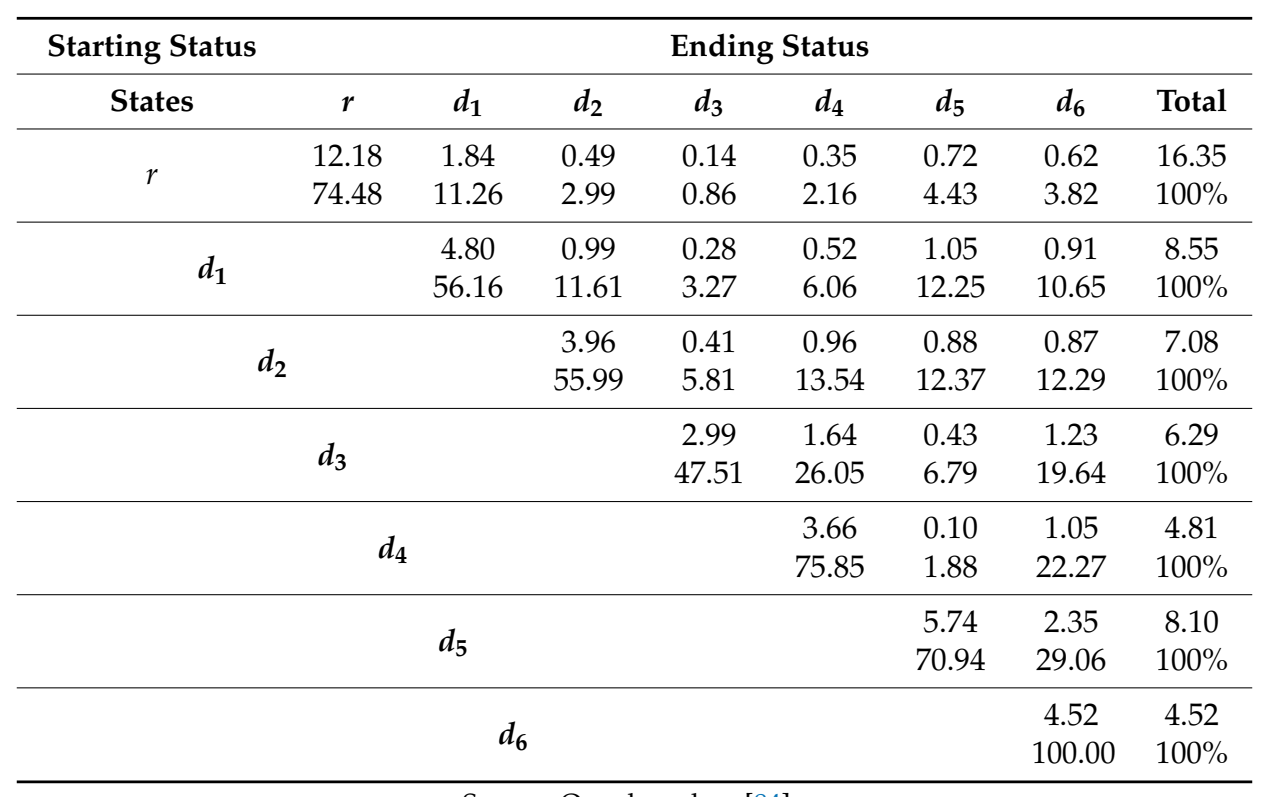

Source: Own based on [84].

Generally speaking, the proportion of total life expectancy likely to be spent in poor health increases with age.

The scheme uses EPAs, in which the uplifts are financed by a reduction-with respect to basic pension $b$ - of the benefit paid while the pensioner is healthy.

In line with the predefined states of dependence, Table 4 shows the (arbitrary) uplifts $\left(\xi_{i j}\right)$ to be applied according to the transitions between the various states that are taken into account in the numerical example.

Table 4. Uplifts $\left(\xi_{i j}\right)$ to be applied when the pensioner moves to a worse health state.

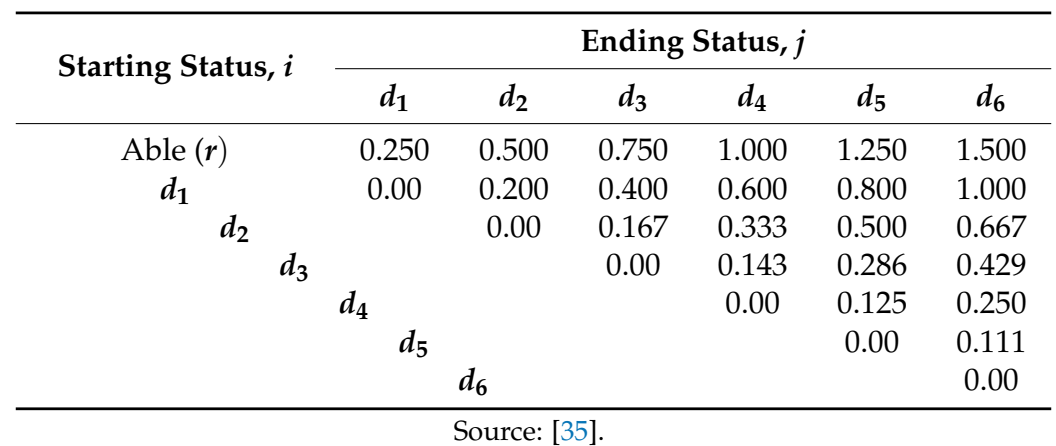

The rows and columns of the matrix embedded in Table 4 refer to the starting and ending health status, respectively, of each pensioner in the cohort. For example, when a healthy person becomes dependent at Level $3\left(r, d_{3}\right)$, the amount of the retirement pension will be $75 \%$ higher than before, given that $\xi_{r 3}=0.75$, whereas the amount of the benefit will be $25 \%$ higher when a Level 4 dependent makes a transition to Level $6\left(d_{4}, d_{6}\right)$.

If we were to put this model into practice, the design structure of the uplifts would be a key element of the system. If the EPA approach were implemented, a large uplift would mean a big reduction in the initial retirement benefit. A crucial step prior to establishing the structure of uplifts for a given country would be to calculate the average yearly cost of care according to the level of severity of dependence and the type of care provided. It would also be very important to take into account the 
cost-sharing or copayment requirements for a given country. However, this goes beyond the scope of this paper, since we are presenting a numerical example to serve only as an illustration.

Table 5 presents the main values that make up the system's equilibrium.

Table 5. NDC system with retirement and graded LTC annuities $\left(N D C_{L T C}\right)$ : some selected values.

\begin{tabular}{|c|c|c|c|c|c|c|c|c|c|c|}
\hline & Items & System & $\mathbf{R}$ & LTC & $d_{1}$ & $d_{2}$ & $d_{3}$ & $d_{4}$ & $d_{5}$ & $d_{6}$ \\
\hline 1 & $\left(\theta_{t}=\theta_{a}\right) \%$ & 16.00 & 13.93 & 2.07 & 0.34 & 0.17 & 0.07 & 0.25 & 0.63 & 0.61 \\
\hline 2 & $\left(\bar{\lambda}_{x}^{d_{j}}>65\right) *$ & 100 & 73.70 & 26.30 & 11.61 & 3.09 & 0.89 & 2.22 & 4.57 & 3.92 \\
\hline 3 & $A F_{(65)}^{L T C(6)}$ & 15.2593 & 10.4582 & 4.8011 & 1.6320 & 0.4949 & 0.1634 & 0.4674 & 1.0779 & 0.9655 \\
\hline 4 & $d r_{t}$ & 0.2722 & 0.2048 & 0.0674 & 0.0297 & 0.0079 & 0.0023 & 0.0057 & 0.0117 & 0.0101 \\
\hline 5 & $f r_{t}$ & 0.5878 & 0.6803 & 0.3069 & 0.1151 & 0.2188 & 0.3229 & 0.4297 & 0.5364 & 0.6024 \\
\hline 6 & $*\left(\theta_{t}=\theta_{a}\right) \%$ & 16.00 & 10.97 & 5.03 & 1.71 & 0.52 & 0.17 & 0.49 & 1.13 & 1.01 \\
\hline 7 & $f r_{t}{ }^{*}$ & 0.5878 & 0.5355 & 0.7468 & 0.5755 & 0.6564 & 0.7534 & 0.8594 & 0.9656 & 1.0041 \\
\hline 8 & $\theta_{t}^{* \%}$ & 12.68 & 11.04 & 1.64 & 0.27 & 0.14 & 0.06 & 0.19 & .50 & 0.48 \\
\hline 9 & $D e_{t} \%$ & & & & & 26.18 & & & & \\
\hline 10 & $T D_{t}$ & 33.44 & 32.53 & 39.59 & 36.67 & 38.64 & 39.26 & 39.29 & 39.35 & 41.93 \\
\hline 11 & $* T D_{t}$ & 33.44 & 30.95 & 38.87 & 36.67 & 38.64 & 39.26 & 39.29 & 39.35 & 41.93 \\
\hline 12 & $A_{r}$ & 74.49 & 73.58 & 80.64 & 77.72 & 79.69 & 80.31 & 80.34 & 80.40 & 82.98 \\
\hline 13 & $* A_{r}$ & 74.49 & 72.00 & 79.92 & 77.72 & 79.69 & 80.31 & 80.34 & 80.40 & 82.98 \\
\hline 14 & $A_{c}$ & & & & & 41.05 & & & & \\
\hline 15 & $\bar{x}_{t}$ & & & & & 64 & & & & \\
\hline 16 & $p t_{c}$ & & & & & 22.95 & & & & \\
\hline 17 & $p t_{r}$ & 10.49 & 9.58 & 16.64 & 13.72 & 15.69 & 16.31 & 16.34 & 16.40 & 18.98 \\
\hline 18 & ${ }^{*} p t_{r}$ & 10.49 & 8.00 & 15.92 & 13.72 & 15.69 & 16.31 & 16.34 & 16.40 & 18.98 \\
\hline
\end{tabular}

Source: Own based on [35]. * This symbol indicates that the selected value has been calculated under the assumption that the total benefits paid to dependent persons are accounted as pension costs attributed to the LTC contingency.

The first item shows that the balanced contribution rate $\left(\theta_{t}\right)$ matches the credited contribution rate $\left(\theta_{a}\right)$. The contribution rate assigned to each contingency, assuming that the criterion for allocating pension costs is the extra benefit paid to the pensioner when a healthy person becomes dependent, is also shown. The contribution rate assigned to each state of dependence depends on the size of the uplift (Table 4) and the LTC prevalence rates (the quotient between the number of dependent persons and the number of pensioners $\left(\bar{\lambda}_{x}^{d_{j}}\right)$, i.e., Item 2$)$, which are determined by the biometric assumptions.

Item 3 shows the value of the annuity factor for the NDC scheme with LTC coverage. For a given pension balance, this divisor determines the initial retirement benefit (see Formula (A1) in Appendix A).

Items 4 and 5 show the value for the demographic ratio, i.e., the quotient between the number of pensioners and the number of contributors $\left(d r_{t}\right)$, and the financial ratio, i.e., the quotient between the average pension and the average contribution base, $\left(f r_{t}\right)$, respectively. The system is in equilibrium because the product of both ratios equals the contribution rate. In the mature state, the contributor-pensioner ratio is 3.67 (the inverse of the demographic ratio) and the system's average replacement rate is $58.78 \%$.

Items 6 and 7 replicate Items 1 and 5, respectively, under the assumption that the total benefits paid to dependent persons are accounted as pension costs attributed to the LTC contingency. In this case, the contribution rate assigned to each status is higher than before. This provides us with a more informative value of the financial ratio by contingency. Naturally, the system's average replacement rate remains unchanged, but the average replacement rates for dependence and retirement do not. Such results make sense because the worse the health status, the higher the average replacement rate.

Item 8 shows that, if the survivor dividend had not been included when calculating the initial retirement pension, a discrepancy would have arisen between the credited contribution rate of $16 \%$ and the rate necessary to finance the system, $\theta_{t}^{*}$, which in this case is $12.68 \%$. The impact of the dividend effect (Item 9) on the initial pension is by no means irrelevant, and the initial retirement pension rises by $26.18 \%$ using the mortality structure for the US derived from Robinson's model. 
Even more important as far as the aim of this paper is concerned are the values for the turnover duration and how they break down (Item 10 onwards).

As Item 10 shows, the TD for LTC in the integrated scheme (39.59 years) is notably different from the base system's TD (33.44 years), and this comes about mainly because the prevalence rates for the most severe dependence states are particularly high for the very elderly. It is calculated assuming that only the uplifts with respect to the pure retirement pension paid to dependent persons are accounted as pension costs attributed to the LTC contingency.

Under the assumption that the total benefits paid to dependent persons are accounted as pension costs attributed to the LTC contingency (Item 11), the TD for LTC (38.87 years) is slightly different from that reported by Item 10. However, the base system's TD (33.44 years) remains unchanged because the weighted average ages of contributors and pensioners and the pay-in and pay-out periods do not change, irrespective of the accounting rules used to record the expenses due to the LTC contingency (see Appendix A).

It is easy to check that the system's TD is a weighted average of the TDs for the contingencies, since the weighting element is the contribution rate per contingency. This is true regardless of the accounting criterion used for recording the disbursements for LTC benefits.

Our example is not far from reality because the resulting values for the turnover duration-between 32.53 and 30.95 years for the pure retirement contingency-do not differ to any great extent from those reported for the contribution asset as calculated by the Swedish authorities. For the period 2012-2016 [10], the TD has ranged from 31.50 to 30.13 years. It could be shorter or longer depending on the biometric assumptions and the uplifts applied. In this and many other ways, the TD will reflect the design of any particular NDC scheme (see Appendix A).

Finally, the breakdown of the system's TD into its principal elements (the pay-in and pay-out periods) conveys very important information enabling a rapid assessment of the relative importance of the liabilities to contributors and pensioners. The pay-in is associated with the liabilities to contributors, whereas the pay-out is associated with the liabilities to pensioners. Given the values estimated for the pay-in and pay-out, it takes no time to calculate that the liabilities to contributors as a proportion of total liabilities amount to $68.63 \%$ in this steady state (see Table 7 later on).

Table 6 presents the main entries on the Swedish-type ABS under three scenarios: the model with no MPB and two that include MPBs. In these two additional scenarios, the pure NDC model is extended from the start by introducing a minimum pension equivalent to $\psi$ percent of the system's average wage. The resulting scheme is now called $N D C_{L T C}^{\psi}$. The MPB is introduced in the two scenarios, respectively, as $\psi=25 \%$, which could be considered as being in line with real pension systems for developed countries, and $\psi=75 \%$, an extreme value that could actually change the nature of the NDC scheme. Amounts are expressed as a percentage of the total assets of the pure NDC model.

Other selected indicators are also shown, such as the contribution rates assigned to each contingency, the balanced contribution rate $\left(\theta_{t}^{*}\right)$ and its decomposition as the product of the dependency ratio and the financial ratio, the degree of funding, and the system's shortfall due to the introduction of an MPB (as a percentage of the aggregate income from contributors, $S h_{t} \%$ ).

The indicators shown include the contribution rates assigned to each contingency under the assumption that the total benefits paid to dependent persons are accounted as pension costs attributed to the LTC contingency.

The ABS for the pure NDC model $\left(N D C_{L T C}\right)$ shows that in this (unrealistic) state the system's total liabilities match perfectly with the system's total contribution asset, since the two integrated contingencies (retirement and LTC) are in financial equilibrium, the solvency ratio is obviously equal to one and the degree of funding and the system's shortfall is zero.

The introduction of an MPB equivalent to $25 \%$ of the system's average wage has a very limited impact on the system's financial equilibrium because only a small proportion of pensioners are granted this new benefit. Under the assumptions adopted, only those with fewer than 17 years of contributions would benefit. Overall, $14.72 \%$ of pensioners would need to top up the capital accumulated in their 
individual accounts because the balance would be less than the minimum required to finance the EPA at the retirement age. Compared to the pure NDC model, the size of the system increases slightly, from 100 to 102.98 , or to 100.94 it if were decided not to recognize the liabilities to contributors due to NCRs. The buffer fund needed to back up the increase in liabilities to contributors and pensioners is very small, 2.98 (0.94), in line with a treasury shortfall that barely amounts to $2.98 \%$ of the aggregate income from contributions. Likewise, the balanced contribution rate (16.48\%) is higher than the rate credited to contributors $(16.00 \%)$, in coherence with the very small rise in the system's financial ratio (from 0.588 to 0.605$)$. The demographic ratio is obviously not affected by the introduction of a minimum pension.

Table 6. The balanced ABS of the $N D C_{L T C}^{\psi}$ scheme at the end of year $t$ as a percent of the total assets of $N D C_{\text {LTC }}$. Some selected values.

\begin{tabular}{|c|c|c|c|c|c|c|c|c|c|}
\hline Items & & $N D C_{L T C}$ & & \multicolumn{3}{|c|}{$N D C_{L T C}^{25 \%}$} & \multicolumn{3}{|c|}{$N D C_{L T C}^{75 \%}$} \\
\hline CA_(R) & \multicolumn{3}{|c|}{63.43} & \multicolumn{3}{|c|}{63.43} & \multicolumn{3}{|c|}{63.43} \\
\hline CA_(LTC) & \multicolumn{3}{|c|}{36.57} & \multicolumn{3}{|c|}{36.57} & \multicolumn{3}{|c|}{$\frac{36.57}{36}$} \\
\hline BF_(LTC) & \multicolumn{3}{|c|}{0.00} & \multicolumn{3}{|c|}{$1.09(0.45)$} & \multicolumn{3}{|c|}{$8.14(3.34)$} \\
\hline \multicolumn{10}{|c|}{ Liabilities } \\
\hline Con_(R) & \multicolumn{3}{|c|}{47.03} & \multicolumn{3}{|c|}{47.03} & \multicolumn{3}{|c|}{47.03} \\
\hline Con_(R) NCR & \multicolumn{3}{|c|}{0.00} & \multicolumn{3}{|c|}{$1.40(0.0)$} & \multicolumn{3}{|c|}{$10.46(0.0)$} \\
\hline Con_(LTC) & \multicolumn{3}{|c|}{21.59} & \multicolumn{3}{|c|}{21.59} & \multicolumn{3}{|c|}{21.59} \\
\hline Con_(LTC) NCR & \multicolumn{3}{|c|}{0.00} & \multicolumn{3}{|c|}{$0.64(0.0)$} & \multicolumn{3}{|c|}{$4.80(0.0)$} \\
\hline Total & & 100.00 & & & $2.98(100$ & & & $22.24(106.9$ & \\
\hline Indicators & & $N D C_{L T C}$ & & & $N D C_{L T C}^{25 \%}$ & & & $N D C_{L T C}^{75 \%}$ & \\
\hline indicators & $\mathbf{R}$ & LTC & $S$ & $\mathbf{R}$ & LTC & $\mathbf{S}$ & $\mathbf{R}$ & LTC & $\mathrm{S}$ \\
\hline$\theta_{a} \%$ & 10.97 & 5.03 & 16.00 & 10.97 & 5.03 & 16.00 & 10.97 & 5.03 & 16.00 \\
\hline$\theta_{t}^{*} \%$ & 10.97 & 5.03 & 16.00 & 11.29 & 5.18 & 16.48 & 13.41 & 6.15 & 19.56 \\
\hline$\theta_{t}^{\cdot} \%$ & 0.00 & 0.00 & 0.00 & 0.33 & 0.15 & 0.48 & 2.44 & 1.12 & 3.56 \\
\hline$d r_{t}$ & 0.205 & 0.067 & 0.272 & 0.205 & 0.067 & 0.272 & 0.205 & 0.067 & 0.272 \\
\hline$f r_{t}$ & 0.535 & 0.748 & 0.588 & 0.552 & 0.769 & 0.605 & 0.655 & 0.913 & 0.719 \\
\hline$D F_{t} \%$ & & 0.00 & & & $2.90(0.93$ & & & $18.20(6.53$ & \\
\hline
\end{tabular}

Source: Own. NB: The totals will not necessarily equal the sums of the rounded components.

For the second MPB scenario $(\psi=75 \%)$, the picture of the system changes considerably. The MPB involves a great number of pensioners and the lower the number of years contributed, the higher the amount of the supplement that the sponsor would have to pay to top up the capital accumulated in the individual accounts. The minimum pension applies to $34.81 \%$ of pensioners, i.e., those with fewer than 44 years of contributions. What first draws the attention in this scenario is the size of the scheme, $22.24 \%$ greater than the benchmark ( $\left.N D C_{L T C}\right)$ under the assumption that liabilities to contributors due to NCRs are recognized. The substantial MPB causes a huge increase in the liabilities acquired by the system. To maintain the system's sustainability, the degree of funding needs to reach a level of $18.20 \%$ of total liabilities, otherwise the sponsor will have to make payments every year to cover the system's recurrent annual deficit, which amounts to $22.24 \%$ of the aggregate income from contributions. In other words, the actual disbursement on pensions would mean a balanced contribution rate of $19.56 \%$ instead of $16.00 \%$. This is a direct consequence of altering the system's average replacement rate from its original value (0.535) to its current value (0.719).

If the liabilities to contributors due to NCRs were not recognized, the buffer fund needed to back up the increase in liabilities due to NCRs would be smaller, amounting to $6.53 \%$ of total (recalculated) 
liabilities. However, the level of payments made by the sponsor would remain the same if the public contribution asset alternative were chosen to underwrite the liabilities to pensioners originating from NCRs.

To summarize, in the situation described above with an MPB embedded in an NDC scheme combining retirement and LTC contingencies, the promotor-i.e., the state-has two options for keeping the system solvent and preserving its transparency. It can either make an extraordinary payment to fully finance the necessary amount of the buffer fund, or it can register a claim on the public purse to regularly remove the system shortfall. The second option makes it possible to record the public contribution asset on the assets side of the ABS.

\subsection{Annual Changes in the System's Financial Position Shown via the Income Statement}

When compiling an ABS for an already-functioning system, other elements may be added to those shown in Table 1 . These could include a buffer fund resulting from an accumulation of treasury surpluses (or simply for liquidity resulting from an extraordinary contribution made by the sponsor (Ss_(R + LTC)), financial liabilities resulting from an accumulation of treasury deficits, actuarial deficits resulting from an accumulation of losses, or actuarial surpluses resulting from an accumulation of gains.

Table 7 presents the ABS of a pure $N D C_{L T C}$ scheme at the end of years $t-1$ and $t$, with changes in net worth determined by comparing the system's assets and liabilities in these consecutive periods. The table also shows the TD for the system and by contingency, the balance ratio (calculated without taking into account the part of the buffer fund corresponding to the sponsor's support), the degree of funding and the liability structure ratio (the ratio between the liabilities to contributors and total liabilities).

Table 7. The ABS of a pure $N D C_{\text {LTC }}$ scheme at the end of years $t$ and $t+1$ with changes in net worth.

\begin{tabular}{|c|c|c|c|}
\hline Items/Year & $t-1$ & $t$ & Variation \\
\hline \multicolumn{4}{|c|}{ Assets } \\
\hline BF & 11.00 & 10.89 & -0.11 \\
\hline CA_(R) & 63.43 & 64.06 & 0.63 \\
\hline CA_(LTC) & 36.57 & 37.26 & 0.69 \\
\hline Ad_( $(\bar{R}+$ LTC $)$ & 0 & 0 & 0.00 \\
\hline L_(R + LTC $)$ & 0 & 1.13 & 1.13 \\
\hline Total & 111 & 113.35 & 2.35 \\
\hline \multicolumn{4}{|c|}{ Liabilities and sponsor support (capital) } \\
\hline Ss_(R + LTC) & 10.00 & 10.00 & 0.00 \\
\hline Con_(R) & 47.03 & 48.21 & 1.18 \\
\hline Con_(LTC) & 21.60 & 22.10 & 0.50 \\
\hline Pen_(R) & 16.39 & 16.80 & 0.41 \\
\hline Pen_(LTC) & 14.98 & 15.25 & 0.27 \\
\hline As_(R + LTC $)$ & 1.00 & 1.00 & 0.00 \\
\hline P_(R + LTC) & 0 & 0 & 0.00 \\
\hline Total & 111 & 113.35 & 2.35 \\
\hline \multicolumn{4}{|c|}{ Solvency, funding and liability structure indicators } \\
\hline $\begin{array}{c}T D_{t}^{S} \\
\left(T D_{t}^{R} ; T D_{t}^{L T C}\right)\end{array}$ & $\begin{array}{c}33.44 \\
(30.95 ; 38.87)\end{array}$ & $\begin{array}{c}33.27 \\
(30.70 ; 38.88)\end{array}$ & -0.017 \\
\hline$B R_{t}^{S}$ & 1.0100 & 0.9987 & -0.0113 \\
\hline$D F_{t}$ & $11.00 \%$ & $10.64 \%$ & -0.0036 \\
\hline$L S_{t}$ & $68.63 \%$ & $68.69 \%$ & 0.0006 \\
\hline
\end{tabular}

Source: Own. NB: The totals will not necessarily equal the sums of the rounded components. 
At the end of year $t-1$, the system's financial position is sound, since the balance ratio is greater than one (1.01), i.e., the accumulated surplus is positive. In general terms, it can be said that this particular system is reasonably solvent, and that therefore at the date of the report the participants (contributors and pensioners) should have a realistic expectation of receiving the benefits that have been accrued, without the system's sponsor (the state) having to make any extraordinary contributions. Such a statement is made on the assumption that the system's rules and the economic and demographic conditions prevailing at the time of the valuation remain constant.

As shown in Table 7, the degree of funding for this system is clearly positive (11\%), mainly due to sponsor support. This allows for possible annual shortfalls in the system's income to be dealt with by selling financial assets.

At the end of year $t$, the system's ABS reports a weaker solvency indicator (0.9987), given that for this period the system registers losses (1.13) larger than the accumulated surplus (1.00). In this situation, the accumulated shortfall becomes positive, i.e., the net worth of the scheme arrives at a negative figure. A more detailed analysis of the balance ratio (see Formula (A32) in Appendix A) shows that the LTC contingency presents a ratio slightly greater than one (1.0065), while the ratio for retirement is less than one (0.9942).

In a case where the system's balance ratio is less than 1, the Swedish NDC system would apply its ABM. This is a legislated formula that reduces the notional interest rate credited to contributions and the indexation rate for pensions, all with the aim of bringing the assets closer to the liabilities. The founders of the Swedish system believed that the issue of financial stability in a public pension system was a matter of social policy, since any imbalance would have to be paid for by someone at some time. They decided that citizens would benefit if the new Swedish public pension plan clearly determined who would pay for any financial imbalance and when [95].

The reasons for acting sooner rather than later in cases where the solvency indicator shows a situation of imbalance are compelling [96]. Early action has important implications when it comes to distributing the burden fairly across generations, and eliminating the insolvency will maintain people's faith in the scheme and make them feel more secure about retirement and other contingencies. Delaying the steps needed to restore full solvency would probably have a negative impact on the government's credit standing [97].

In a pessimistic scenario where the $\mathrm{ABM}$ is permanently triggered, there would be no assurance that benefit amounts would not fall below accepted levels [98]. This hypothetical problem clearly goes beyond the scope of this paper.

Returning to Table 7, we see that in this accounting period the system has recorded losses because the difference between the increase in assets (1.22) and the increase in liabilities (2.35) is negative $(-1.13)$.

To conclude this part of the numerical example, the detailed changes in the system's financial position are shown on the income statement (Table 8). 
Table 8. The income statement for the period $t-1$ and $t$.

\begin{tabular}{cccc}
\hline ITEMS & System & $\mathbf{R}$ & LTC \\
\hline FUND ASSET (Changes) & $-\mathbf{0 . 1 1}$ & $-\mathbf{0 . 0 7}$ & $-\mathbf{0 . 0 4}$ \\
Pension contributions & 3.05 & 2.09 & 0.96 \\
Pension disbursements & -3.20 & -2.19 & -1.01 \\
Return on funded capital & 0.04 & 0.03 & 0.01 \\
CONTRIBUTION ASSET (Changes) & $\mathbf{1 . 3 3}$ & $\mathbf{0 . 6 3}$ & $\mathbf{0 . 6 9}$ \\
Value of change in contribution revenue & 1.83 & 1.15 & 0.69 \\
Value of change in turnover duration & -0.50 & -0.51 & 0.01 \\
Total DEBIT SIDE & $\underline{\mathbf{1 . 2 2}}$ & $\mathbf{0 . 5 6}$ & $\mathbf{0 . 6 5}$ \\
LIABILITIES (Changes) & $\mathbf{2 . 3 5}$ & $\mathbf{1 . 5 9}$ & $\mathbf{0 . 7 7}$ \\
New pension credit & 3.05 & 2.09 & 0.96 \\
Pension disbursements & -3.20 & -2.19 & -1.01 \\
Indexation & 2.34 & 1.56 & 0.79 \\
Value of change in life expectancy & 0.13 & 0.13 & -0.00 \\
Value of change in biometric assumptions & 0.03 & 0.00 & 0.03 \\
NET WORTH (change) & $\mathbf{- 1 . 1 3}$ & $\mathbf{- 1 . 0 2}$ & $-\mathbf{0 . 1 1}$ \\
Total CREDIT SIDE & $\underline{\mathbf{1 . 2 2}}$ & $\underline{\mathbf{0 . 5 7}}$ & $\underline{\mathbf{0 . 6 6}}$
\end{tabular}

Source: Own. NB: The totals will not necessarily equal the sums of the rounded components.

The system has a cash flow deficit because income from contributions falls short of pension outlays. This shortfall is absorbed by the buffer fund, but the return on funded capital does not cover the entire cash flow deficit. This is also true if we examine the change in fund assets by contingency.

The ratio between pension contributions and pension disbursements is approximately $95.24 \%$, so the system has a treasury shortfall that amounts to $4.76 \%$ of the aggregate income from contributions.

Changes in the contribution asset add net worth to the system (1.33), but the value of the change in the system's turnover duration decreases the asset by the amount shown $(-0.51)$. Nevertheless, the value for the LTC contingency is positive, given that its associated TD is slightly higher in $t(38.88)$ than in $t-1$ (38.87).

The analysis of changes in liabilities shows that the pension liability increases mainly with the annual indexation of pensions and pension account balances (2.34). Indexation here is determined by the change in the growth of the annual wage bill. It can be seen that the value of the change in life expectancy also increases the pension liabilities. For the LTC contingency, the value of the change in biometric assumptions shows a positive amount of 0.03 monetary units, which leads to an increase in LTC pension liabilities. If this trend persists over time, it could indicate an expansion of morbidity. The change in net worth is the result of all the above, and in this case the system has losses of 1.13 monetary units. Given that the system had an accumulated surplus (also known as the opening results brought forward) of 1 monetary unit, then the closing results brought forward (or the system's net worth) amounts to -0.13 monetary units.

To summarize, changes in net worth in this type of NDC scheme are affected by economic and demographic factors and by financial markets if the system has a reserve fund. The main factor in the short term would usually be growth in employment and the contribution base, but demographic factors would be far more important in the long term.

If the degree of funding were large enough, the effect of major changes in the financial markets would also be very significant in the short term. This was the case with the Swedish NDC system in 2008. The main reason for the year's negative result was the decrease in the buffer fund assets due to the severe crisis that affected the world's financial markets. The main consequence was that the balance ratio dropped below 1.0000 for the first time, and this was reflected in pensioners' pockets and contributors' pension accounts from 2009 to 2010 [99]. Pensioners with only a guaranteed minimum pension or a low benefit were unaffected. 


\section{Summary, Conclusions and Future Research}

There are solid reasons for proposing to link old-age income and LTC policy in the public pension system. LTC finance needs to be considered as part of an overall retirement strategy rather than as a simple extension of health insurance, and the rationale behind all pension arrangements is to provide an adequate income to meet needs in retirement regardless of a person's state of health. For most retirement planners, retirement and LTC often go hand-in-hand and the combination of both contingencies is a way of improving the spread of LTC social insurance coverage. In addition, pooling the longevity risk (associated with pure retirement benefit) and the morbidity risk (associated with the unhealthy states of the beneficiaries) should result in a more efficient scheme due to the lower overall risk, since both risks work in opposite directions.

In OECD countries, there are significant concerns about the sustainability of financing LTC services and other assistance for the elderly [52]. This is not surprising given that an increased demand for LTC services (and an increase in associated costs) is forecast in various countries including the UK, Germany, Spain, Italy, Japan, Canada, Chile, the US and China, to name just a few [51,53].

In short, it is difficult to hide the real importance of this subject, i.e., the link between retirement and LTC contingencies and the need to find the right balance between fair protection and financial sustainability in the long term, but without shifting too large a financial burden onto future generations.

The idea of combining the retirement and LTC contingencies embedded in an NDC scheme and using CFC benefits to help pensioners to cope with the cost of LTC is in line with beneficiary choice and flexibility, which are increasingly important goals in modern LTC systems. This proposal aims to provide financial sustainability in the long term and enhance intergenerational equality.

With all the above reasons in mind, this paper has developed the necessary technicalities to present a Swedish-type financial reporting statement for an NDC scheme embedding LTC insurance within the retirement pension system. The articles [34,35] and the current financial report of the Swedish NDC scheme [10] were the cornerstones enabling the paper's aim to be achieved.

The proposed social insurance accounting model, in line with the principle of separating the distributional aspects of social policy from the contributory aspect of the NDC scheme, splits the system into two parts: the pure NDC part and the redistributive part, which includes the assets and liabilities originating from NCRs. The paper has shown that, in theory at least, an NDC system combining retirement and LTC would be financially sound, i.e., the proposed model as a whole is coherent. In a mature state, the balance ratio indicates that the amount of the system's assets perfectly matches the amount of the system's liabilities. It is also shown that prefunding and sustainability are not necessarily linked.

In the specific case of an NDC that includes an MPB, to keep the system sustainable and preserve its transparency, the asset side of the balance sheet should include a corresponding counterpart to cover the commitments to pensioners and contributors due to NCR rights. Two valid options have been explored. These involve either making an extraordinary contribution to fully finance the necessary amount of the buffer fund or registering a claim on the public purse to regularly remove the system's shortfall, and this second option makes it possible to record the public contribution asset on the assets side of the ABS. The use of a buffer fund has the advantage of forcing politicians to guarantee pension promises made in the shape of MPBs, since the higher the level of the stipulated MPB, the higher the degree of funding needed to maintain the system's financial equilibrium.

The paper has also shown that this social insurance accounting methodology, based on a present value model, is valid when it comes to measuring the scheme's financial health over time by means of the balance ratio. This income statement contains very useful information about the demographic and economic factors affecting the change in the system's net worth by contingency. This is very valuable information for stakeholders.

In line with the reference model [10], our proposed way of measuring the pension system's assets and liabilities has several advantages-it has a high degree of transparency and needs no complicated projections of economic, financial or demographic variables, which could easily have a bias effect on 
the sustainability and solvency indicators [27]. Anyone with any knowledge of financial matters can understand the ABS and the way it expresses the pension system's financial situation [28].

To a certain extent, the ABS is easy to compile because it is based on a simple process of calculating both the assets from contributions and the liabilities to pensioners and contributors (from the amounts accumulated in their individual notional accounts). In this regard, we should bear in mind that, in the context of academic analysis and research, complex models and frameworks with various assumptions and sensitivity analyses may be suitable. However, in the context of practical rules and real policy, the frameworks may need to be designed to be more straightforward [18].

Finally, no projections need to be made when compiling the ABS. If the solvency indicator that emerges from the ABS is less than 1 and this triggers an ABM, the possibly endless debate as to the accuracy of projections is avoided. Applying the necessary adjustment should not give rise to any discussion unless the reasons for applying the ABM are temporary and easily reversed.

The main disadvantage of the approach is that it is not sensitive to economic and demographic uncertainty. Because the ABS is based on verifiable facts and transactions at the date on which it is compiled, no projections are carried out and therefore no demographic or economic threats to the system are taken into account. However, this problem can easily be overcome in the same way as in Sweden, where projections are made of the actuarial balance itself, although these are never used to decide whether to activate the ABM [10].

On the practical side, the numerical illustration we present can to a great extent be considered realistic for several reasons. The model works simultaneously with 49 and 37 generations of contributors and pensioners, respectively, and takes into account the effect of the survivor dividend on the system's financial equilibrium. The pensioners' health statuses have been divided into seven different states based on accurate biometric data, given that publicly-run LTC schemes recognize at least three degrees of dependence. Moreover, the resulting values for the turnover duration do not differ greatly from those reported by the Swedish authorities.

The example we develop adds value to the paper because it sheds light on the main differences with the benchmark model [10], which only includes the retirement contingency. The results make sense and provide us with some useful values regarding the impact of introducing a minimum pension on the system's financial equilibrium. Furthermore, the example clearly shows that this accounting framework integrates both contributory and social aspects of public pensions and discloses the real cost of redistribution through minimum pensions.

Ignoring the fact that the proposed scheme is not yet in force in any country, another valuable lesson to be drawn from the numerical illustration is that putting the model into practice would demand accurate annual estimates of mortality, transition and incidence rates, which is highly complex for technical reasons and/or due to a lack of reliable data.

To conclude, the paper stresses the need for the proper reporting of social insurance benefits to enhance transparency and sustainability and improve decision-making, all of which is in the public interest. It shows that the relationship between this accounting framework and ABMs comes about naturally. When the solvency indicator reveals that the system's balance ratio is less than 1 , the logical step is to trigger the ABM to restore solvency as soon as possible.

Finally, considering the model presented here, one direction for future research would be to extend this accounting framework to cover a more comprehensive NDC scheme combining retirement, LTC and permanent disability. To do this, however, a preliminary (difficult) step would involve designing this new proposed NDC scheme, which would necessarily be a time-consuming task.

Author Contributions: Conceptualization, C.V.-M. and M.V.-M.; Methodology, C.V.-M.; Software, M.V.-M. and J.M.P.-S.G.; Formal Analysis, M.V.M.; Writing—Original Draft Preparation, C.V.-M.; Writing—Review and Editing, J.M.P.-S.G.; and Visualization, J.M.P.-S.G.

Funding: The authors are grateful for the financial assistance received from the Spanish Ministry of the Economy and Competitiveness (Ministerio de Economía y Competitividad) project ECO2015-65826-P. 
Acknowledgments: We would like to thank seminar participants at the Universities of Barcelona, Valencia and UPO of Sevilla; Peter Hall for his help with the English text; and Javier Pla-Porcel for his invaluable help in performing the numerical example. The comments and suggestions made by five anonymous referees and Special editors Hagemejer and Polakowski were very helpful in improving the current version. Any errors are entirely our own.

Conflicts of Interest: The authors declare no conflict of interest.

\section{Abbreviations}

$\begin{array}{ll}\text { ABM } & \text { Automatic balance mechanism } \\ \text { ABS } & \text { Actuarial balance sheet } \\ \text { ADL } & \text { Basic activities of daily living } \\ \text { BF } & \text { Buffer fund } \\ \text { CA } & \text { Contribution asset } \\ \text { CFC } & \text { Cash for care benefits } \\ \text { DB } & \text { Defined benefit } \\ \text { DC } & \text { Defined contribution } \\ \text { EPA } & \text { Enhanced pension annuity } \\ \text { G } & \text { Covered wage bill growth } \\ \text { GA } & \text { Generational accounting } \\ \text { GDP } & \text { Gross domestic product } \\ \text { IADL } & \text { Instrumental activities of daily living } \\ \text { LCA } & \text { Life care annuity } \\ \text { LTC } & \text { Long-term care } \\ \text { MOLG } & \text { Multistate overlapping generations model } \\ \text { MPB } & \text { Minimum pension benefit } \\ \text { NCR } & \text { Non-contributory rights } \\ \text { NDC } & \text { Notional defined contribution } \\ \text { OASDI } & \text { Old age, survivors and disability insurance } \\ \text { OECD } & \text { Organization for Economic Co-operation and Development } \\ \text { PAYG } & \text { Pay-as-you-go } \\ \text { PCA } & \text { Public contribution asset } \\ \text { TD } & \text { Turnover duration } \\ \end{array}$

\section{Appendix Technical Appendix}

\section{Appendix A.1 The Basic Elements of the Model:}

The accounting framework for organizing, summarizing and interpreting data on transfer systems and the life cycle developed in [100-104] combined with the standard double-entry bookkeeping method can be considered the structural basis of this paper.

Arthur and McNicoll [100] integrated mathematical demography into the Samuelson model and highlighted the importance of the age profiles of labor income and consumption, a theme continued in [101]. Willis [104] derived some key accounting identities and comparative static results, and then Lee [102] and Lee [103] further developed the Willis model.

The papers cited above along with the seminal work by Samuelson [105], who introduced overlapping generation models into economics and highlighted the importance of intergenerational transfers, are the basis of the so-called national transfer accounts. This methodology provides a coherent accounting framework of economic flows from one age group or generation to another, typically for a national population in a given calendar year [106].

The "Italian method" of double-entry bookkeeping is the foundation for modern accounting [107]. It can be defined as "that system by which every transaction involving a transfer of money or money's worth is recorded in two separated parts of a series, not merely by way of repetition, but so as to record the two distinct aspects in which every such transaction is capable of being regarded" [108].

This paper combines the above accounting framework with a multiple state transition model $[57,61]$, which describes a subject's movements between a set of various states: contributors (active) (a), retired (healthy) $(r)$, retired $\left(j \in\{1,2, \ldots, n\}\right.$-level dependent) $\left(d_{j}, j \in\{1,2, \ldots, n\}\right)$, and deceased $(f)$.

From a pension mathematics point of view, the model for calculating the annuity factors can be seen as a multi-state non-homogeneous discrete Markov process, $\left\{S(t), t \in \mathbb{Z}^{+}\right\}$, where $S(t)$ is the random variable that 
represents the process state at time $t$ with values in a finite state space, $\mathcal{S}=\left\{a, r, d_{1}, \ldots \ldots, d_{n}, f\right\}$, with just one state at any time and a set of direct possible unidirectional ordered pair transitions

$$
\mathcal{T}=\left\{\begin{array}{l}
(a, r),(a, f),\left(r, d_{1}\right), \ldots \ldots,\left(r, d_{n}\right),(r, f),\left(d_{1}, d_{2}\right), \ldots \ldots \ldots,\left(d_{1}, d_{n}\right),\left(d_{1}, f\right), \\
\left(d_{2}, d_{3}\right), \ldots \ldots \ldots \ldots \ldots,\left(d_{2}, d_{n}\right),\left(d_{2}, f\right), \ldots \ldots \ldots \ldots,\left(d_{n-1}, d_{n}\right),\left(d_{n-1}, f\right),\left(d_{n}, f\right)
\end{array}\right\}
$$

The process is non-homogeneous if we take into account the age of the individuals.

In this type of process, transition probabilities depend only on the current state of the process. Therefore, pair $(\mathcal{S}, \mathcal{T})$ is the multiple state model used. It can be said that this framework modeled using Markov assumptions enables the easy computation of relevant probabilities and expected values.

In short, our approach can be termed a multiple overlapping generations model (MOLG), which is the cornerstone of our accounting framework and enables us to compute the percentage of the retired population receiving LTC benefits in a mature state. To a large extent, the model includes realistic demography because it takes into account an age and health status schedule of mortality, the uncertainty that surrounds the timing of becoming dependent (LTC incidence rates by age) and yearly deterioration probabilities by age (probabilities of moving to a worse state of dependence). It also allows for changes in population and for a large number of generations of contributors and pensioners (active and dependent persons classified by their degree of LTC needs) to coexist at each moment in time.

\section{Appendix A.2 Determining the Average Initial Pension (Pure NDC Scheme):}

The average initial benefit (with survivor dividend) for an individual aged $x_{e}+A$ in year $t$, enhanced by percentages $\left\{\xi_{r 1}, \xi_{r 2}, \ldots, \xi_{r n}\right\}$ if the healthy person becomes dependent, $\bar{P}_{\left(x_{e}+A, t\right)}^{N D C}$, can be expressed as:

$$
\bar{P}_{\left(x_{e}+A, t\right)}^{N D C}=\frac{\bar{K}_{\left(x_{e}+A, t\right)}^{a c}}{A F_{\left(x_{e}+A\right)}^{L T C(n)}}=\frac{\frac{K_{\left(x_{e}+A, t\right)}^{T a c}}{l_{\left(x_{e}+A, t\right)}}}{\ddot{a}_{x_{e}+A}^{r \alpha}+\sum_{j=1}^{n} \xi_{r j} A_{x_{e}+A}^{r d_{j} \alpha}}
$$

where

$x_{e}$ is the earliest age of entry into the system. The age giving entitlement to retirement pension is $x_{e}+A$.

$\bar{K}_{\left(x_{e}+A, t\right)}^{a c}=\frac{K_{\left(x_{e}+A, t\right)}^{\mathrm{Tac}}}{l_{\left(x_{e}+A, t\right)}}$ is the average accumulated notional capital at time $t$ for individuals aged $x_{e}+A$.

$A F_{\left(x_{e}+A\right)}^{L T C(n)}$ is the annuity factor of the system with LTC coverage (this expression is fully developed in the paper by [109] for a more general case including the possibility of recovery).

$K_{\left(x_{e}+A, t\right)}^{T a c}=\theta_{a} \cdot \sum_{k=0}^{A-1} l_{\left(x_{e}+k, k+t-A\right)} \cdot y_{\left(x_{e}+k, k+t-A\right)} \cdot(1+G)^{A-k}$ is the total accumulated notional capital at time $t$ for all individuals who reach age $x_{e}+A$.

$y_{\left(x_{e}+k, k+t-A\right)}$ is the average wage (contribution base).

$l_{\left(x_{e}+A, t\right)}$ is the number of contributors at time $t$ for individuals aged $x_{e}+A$.

$\ddot{a}_{x_{e}+A}^{r \alpha}$ is the present value at age $x_{e}+A$ of 1 monetary unit of a lifetime pension payable in advance while the individual is healthy, indexed at rate $\alpha$ with a technical interest rate equal to $G$.

$\xi_{r j} A_{x_{e}+A}^{r d_{j} \alpha}$ is the present actuarial value, for a healthy person aged $x_{e}+A$, of the graded LTC annuity or enhanced pension that supplements 1 monetary unit of the initial retirement pension by percentage $\xi_{r j}$, where $j \in\{1,2, \ldots n\}$ and $0<\xi_{r 1}<\xi_{r 2}<\ldots<\xi_{r n}$. The enhanced benefits are paid from the moment the healthy person becomes dependent and for as long as they remain in a state of dependence.

\section{Appendix A.3 The Average Initial Pension with a Minimum Pension Benefit:}

The amount of the initial retirement pension awarded to pensioners in year $t$ is the highest of either the benefit computed according to Formula (A1), $\left(\bar{P}_{\left(x_{e}+A, t\right)}^{N D C}\right)$, or the minimum pension, $\left(\bar{P}_{(\bar{y}, t)}^{M i n}\right)$ :

$$
\bar{P}_{\left(x_{e}+A, t\right)}=\operatorname{Max}\left\{\bar{P}_{\left(x_{e}+A, t\right)}^{N D C[r]}, \bar{P}_{(\bar{y}, t)}^{\operatorname{Min}[r]}\right\}
$$

For the following years, assuming that all pensions are indexed at the same rate and that $k\left\{1,2, \ldots \omega-\left(x_{e}+A\right)\right\}$, the benefit will depend on the health status of the pensioner, $\bar{P}_{\left(x_{e}+A+k, t+k\right)}=$ $\operatorname{Max}\left\{\bar{P}_{\left(x_{e}+A+k, t+k\right)}^{N D C[\Omega]}, \bar{P}_{(\bar{y}, t+k)}^{\operatorname{Min}[\Omega]}\right\}$, where $\Omega \in\left\{r, d_{1}, \cdots, d_{n}\right\}$, and, because a higher level of LTC means greater expense for the annuitant, the amount of the minimum pension in the case of LTC need is fully linked to retirement. 
With population growth of $\gamma>0$, there are $A$ different contribution pathways that will determine $A$ different pensions, since contributors might be working for 1 year, 2 years ..., $A$ years.

$$
l_{\left(x_{e}+A, t\right)}=\sum_{c=1}^{A} l_{\left(x_{e}+A, c, t\right)} ; \quad K_{\left(x_{e}+A, t\right)}^{a c T}=\sum_{c=1}^{A} K_{\left(x_{e}+A, c, t\right)}^{a c} \cdot l_{\left(x_{e}+A, c, t\right)}
$$

where

$l_{\left(x_{e}+A, c, t\right)}$ is the number of individuals who retire at age $x_{e}+A$ and have been contributing for the last $c$ years at time $t$.

$K_{\left(x_{e}+A, c, t\right)}^{a c}$ is the accumulated notional capital at time $t$ for one individual aged $x_{e}+A$ who has been contributing for the last $c$ years.

The average initial pension for individuals who retire at the retirement age, $\bar{P}_{\left(x_{e}+A, t\right)}$, is a weighted average of the $A$ different pensions once settled. To determine this benefit, the system does not take into account the contributions made (if any) by the contributor before joining the scheme:

$$
\bar{P}_{\left(x_{e}+A, t\right)}=\frac{\bar{K}_{\left(x_{e}+A, t\right)}^{a c}}{A F_{\left(x_{e}+A\right)}^{L T C(n)}}+\overline{S P}_{\left(x_{e}+A, t\right)}=\bar{P}_{\left(x_{e}+A, t\right)}^{N D C}+\overline{S P}_{\left(x_{e}+A, t\right)}
$$

where $\overline{S P}_{\left(x_{e}+A, t\right)}$ is the average supplementary retirement benefit at time $t$, defined as:

$$
\overline{S P}_{\left(x_{e}+A, t\right)}=\frac{\sum_{c=1}^{A} \operatorname{Max}\left\{P_{(\bar{y}, c, t)}^{M I N}-P_{\left(x_{e}+A, c, t\right)}^{N D C}, 0\right\} \cdot l_{\left(x_{e}+A, c, t\right)}}{l_{\left(x_{e}+A, t\right)}}=\frac{V \overline{S P}_{\left(x_{e}+A, t\right)}}{A F_{\left(x_{e}+A\right)}^{L T C(n)}}
$$

where $V \overline{S P}_{\left(x_{e}+A, t\right)}$ is the difference between the present value of the positive differences between the minimum pensions awarded and the account balances of participants available at the time of retirement $(t)$ for age $x_{e}+A$, under the assumption that all pensions are indexed at the same rate $(\alpha)$. In this case, the concept can be formalized as:

$$
V \overline{S P}_{\left(x_{e}+A, t\right)}=\sum_{c=1}^{A} \frac{\operatorname{Max}\left\{P_{(\bar{y}, c, t)}^{M I N}-P_{\left(x_{e}+A, c, t\right)}^{N D C}, 0\right\} \cdot l_{\left(x_{e}+A, c, t\right)}}{l_{\left(x_{e}+A, t\right)}} \cdot A F_{\left(x_{e}+A\right)}^{L T C(n)}
$$

The total spending on new retirement pensions awarded in year $t$ can be expressed as:

$$
\bar{P}_{\left(x_{e}+A, t\right)} \cdot l_{\left(x_{e}+A, t\right)}=[\underbrace{A F_{\left(x_{e}+A\right)}^{L T C(n)}}_{\bar{K}_{\left(x_{e}+A, t\right)}^{a c}}+\overline{S P}_{\left(x_{e}+A, t\right)}] \cdot l_{\left(x_{e}+A, t\right)}
$$

\section{Appendix A.4 The System's Turnover Duration (TD) and Contribution Asset (CA):}

If the rules of the pension system, mainly the contribution rate applied and the way the initial benefits are computed, and the demographic and economic framework detailed in the benchmark model are taken into account, then the process for obtaining the system's liabilities and the analytical expressions for the system's turnover duration $(T D)$ and contribution asset $(C A)$ can be separated into four additional steps [31,34]:

1. The analytical expressions for the system's liabilities from the actuarial point of view.

2. The analytical expression for the system's $T D$ in the form of pay-out and pay-in durations.

3. The expression for the TD as the difference in the weighted average ages of the pensioners and contributors.

4. The system's TD and $C A$ as weighting for the TDs and $C A s$ for each contingency.

After some modifications, applying the last three steps to the NDC scheme with retirement and LTC is not a difficult task, but the application of Step 1 needs to be revisited in depth.

\section{Appendix A.5 The Liabilities Side}

The entries shown on the right-hand side of Table 1 are detailed below under the assumption that the system is in a mature state. Once the system reaches the mature state $t=\omega-x_{e}-A$ years from inception, it pays full 
benefits to all generations of pensioners irrespective of their health status. The contribution rate that guarantees equality between contribution revenue and pension expenditure is constant over time and is the product of the stabilized demographic ratio and the financial ratio. The financial ratio is constant because the average pension and average contribution base both evolve at the rate of variation in wages.

The social insurance accounting proposal splits the system into two parts: the pure NDC part and the redistributive part, which includes the assets and liabilities originating from non-contributory rights (NCRs).

\section{Appendix A.5.1 The NDC Part}

- Liability to pensioners for retirement

For able/healthy pensioners, the NDC liability can be expressed as:

$$
N D C[R] V_{t}^{r}=\sum_{k=0}^{w-\left(x_{e}+A\right)} \bar{P}_{\left(x_{e}+A+k, t\right)}^{N D C[r]} \cdot l_{\left(x_{e}+A+k, t\right)}^{r} \cdot \underbrace{\left(\ddot{a_{x_{e}}+A \alpha+k}+\sum_{j=1}^{n} \xi_{r j} A_{x_{e}+A+k}^{r d_{j} \alpha}\right)}_{A F_{\left(x_{e}+A+k\right)}^{L T C(n)}}
$$

where

$\bar{P}_{\left(x_{e}+A+k, t\right)}^{N D C[r]}$ is the average pension for healthy pensioners by age at time $t$.

$l_{\left(x_{e}+A+k, t\right)}^{r}$ is the number of healthy pensioners by age at time $t$.

$A F_{\left(x_{e}+A+k\right)}^{L T C(n)}$ is the actuarial discount factor for healthy pensioners by age (see Formula (A1)).

- Liability to pensioners for LTC

The NDC liabilities with respect to the $i \in\{1,2, \cdots, n\}$ grade pensioners can be expressed as:

$$
N D C\left[d_{i}\right] V_{t}^{r}=\sum_{k=1}^{w-\left(x_{e}+A\right)} \bar{P}_{\left(x_{e}+A+k, t\right)}^{N D C\left[d_{i}\right]} \cdot l_{\left(x_{e}+A+k, t\right)}^{d_{i}} \cdot \overbrace{\left(\ddot{a}_{x_{e}+A+k}+\sum_{j=1}^{n} \xi_{i j} A_{x_{e}+A+k}^{d_{i} d_{j} \alpha}\right)}^{A F_{\left(x_{e}+A+k\right)}^{L T C(i, n)}}
$$

where

$\bar{P}_{\left(x_{e}+A+k, t\right)}^{N D C\left[d_{i}\right]}$ is the average pension for pensioners in the $i$ level of dependence by age at time $t$.

$l_{\left(x_{e}+A+k, t\right)}^{d_{i}}$ is the number of retired people in the $i$ level of dependence by age at time $t$.

$A F_{x_{e}+A+k}^{L T C}(i, n)$ is the actuarial discount factor for pensioners in the $i$ level of dependence by age. In the particular case of $i=n, A F_{x_{e}+A+k}^{L T C}(n, n)=\ddot{a} x_{x_{e}+A+k}$.

$\ddot{a}_{x_{e} \alpha+A+k}^{d_{i} \alpha}$ is the present value at age $x_{e}+A+k$ of 1 monetary unit of a lifetime pension payable in advance while the pensioner remains in the $i$ level of dependence, indexed at rate $\alpha$ with a technical interest rate equal to $G$.

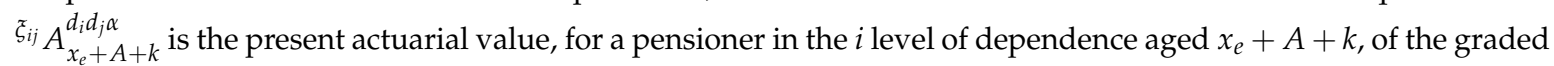
LTC annuity that supplements 1 monetary unit of their LTC pension by percentage $\xi_{i j}$, where $j \in\{1,2, \ldots n\}$ and $j>i$. The enhanced benefits are paid from the moment the pensioner makes a transition to a worse health state and for as long as they remain in this state of dependence.

The total NDC liabilities to pensioners for LTC are:

$$
{ }^{N D C}[L T C] V_{t}^{r}=\sum_{i=1}^{n}{ }^{N D C}\left[d_{i}\right] V_{t}^{r}
$$

- Liability to contributors for retirement

For the retirement contingency, the NDC liability to current contributors is equal to:

$$
{ }^{N D C[R]} V_{t}^{c}=\sum_{k=1}^{A} K_{\left(x_{e}+k, t\right)}^{\operatorname{Tac}(R)}=\theta^{R} \cdot\left(\sum_{k=1}^{A} \sum_{s=0}^{k-1} l_{\left(x_{e}+s, t\right)} \cdot y_{\left(x_{e}+s, t\right)}\right)
$$

where 
$K_{\left(x_{e}+k, t\right)}^{\operatorname{Tac}(R)}$ is the total accumulated notional capital for retirement at time $\mathrm{t}$ for individuals aged $x_{e}+k$.

$\theta^{R}$ : is the defined contribution rate for retirement.

$y_{\left(x_{e}+s, t\right)}$ is the average wage by age at time $t$.

The notional account is an accumulation of the contributions made, the survivor dividend distributed and the returns generated over the participant's working life. Formula (A11) includes the distributed survivor dividend, given that it takes into account all the contributions made by all the contributors (living or dead at time $t$ ). It is easy to demonstrate that:

$$
\sum_{s=0}^{k-1} l_{\left(x_{e}+s, t-k+s\right)} \cdot y_{\left(x_{e}+s, t-k+s\right)} \cdot(1+G)^{k-s}=\sum_{s=0}^{k-1} l_{\left(x_{e}+s, t\right)} \cdot y_{\left(x_{e}+s, t\right)}
$$

This liability is calculated using notional philosophy, i.e., the liability to contributors is the sum of the pension balances allocated to retirement of all active contributors. This procedure is equivalent to the accumulated benefit obligations approach used when estimating the accrued-to-date liabilities. It corresponds to the benefits that a contributor would receive if the plan were shut down today and is thus often called the "termination" liability.

- Liability to contributors for LTC

The NDC liability to contributors for LTC is:

$$
{ }^{N D C}[L T C] V_{t}^{c}=\sum_{k=1}^{A} K_{\left(x_{e}+k, t\right)}^{T a c(L T C)}=\theta^{L T C} \cdot\left(\sum_{k=1}^{A} \sum_{s=0}^{k-1} l_{\left(x_{e}+s, t\right)} \cdot y_{\left(x_{e}+s, t\right)}\right)
$$

where

$K_{\left(x_{e}+k, t\right)}^{T a c(R)}$ is the total accumulated notional capital for LTC at time $t$ for individuals aged $x_{e}+k$.

$\theta^{L T C}$. is the defined contribution rate for LTC.

The total NDC liability to current contributors is:

$$
{ }^{N D C} V_{t}^{c}={ }^{N D C[R]} V_{t}^{c}+V^{N D C[L T C]} V_{t}^{c}
$$

Formulas (A11) and (A13) show that the pension balances have been separated into contingencies, but this is not strictly necessary.

Under the assumption of a mature state-which means that contributions perfectly match pension payments so the accumulated deficit and accumulated surplus are zero- the system's total NDC liabilities $\left({ }^{N D C} V_{t}^{S}\right)$ are also the sum of all the liabilities decribed above:

$$
{ }^{N D C} V_{t}^{S}=\overbrace{{ }^{N D C[R]} V_{t}^{r}+{ }^{N D C[L T C]} V_{t}^{r}}^{\text {Pensioners }}+\underbrace{N D C[R] V_{t}^{c}+{ }^{N D C[L T C]} V_{t}^{c}}_{\text {Contributors }}
$$

\section{Appendix A.5.2 The Redistributive Part (NCR)}

- Liability to pensioners for retirement

$$
N C R[R] V_{t}^{r}=\sum_{k=0}^{w-\left(x_{e}+A\right)} V \overline{S P}_{\left(x_{e}+A+k, t\right)}^{R} \cdot l_{\left(x_{e}+A+k, t\right)}^{r}
$$

where $V \overline{S P}_{\left(x_{e}+A+k, t\right)}^{r}$ is the present value of the average supplementary retirement benefit by age at time $t$.

- Liability to pensioners for LTC

$$
{ }^{N C R[L T C]} V_{t}^{r}=\sum_{k=1}^{w-\left(x_{e}+A\right)} V \overline{S P}_{\left(x_{e}+A+k, t\right)}^{L T C} \cdot l_{\left(x_{e}+A+k, t\right)}^{L T C}
$$

where $V \overline{S P}_{\left(x_{e}+A+k, t\right)}^{L T C}$ is the present value of the average supplementary LTC graded benefit by age at time $t$.

- Liability to contributors for retirement and LTC

As stated in Section 2.2, the inclusion of an MPB implies the valuation of the accrued minimum benefit by means of the prospective and forecasting method. Obviously, this amount, $V_{t}^{c}$, will be higher than the sum of the 
pension balances of active contributors, ${ }^{N D C} V_{t}^{c}$, the difference being the liability to contributors for retirement and LTC.

For retirement:

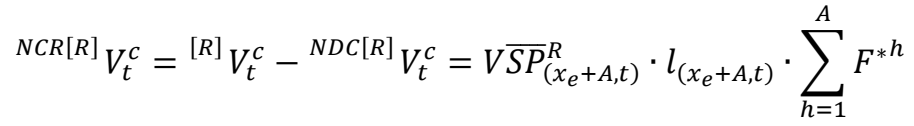

$$
\begin{aligned}
& =\overbrace{\left(\bar{P}_{\left(x_{e}+A, t\right)}-\bar{P}_{\left(x_{e}+A, t\right)}^{N D C}\right)}^{\overline{S P}_{\left(x_{e}+A, t\right)}} \cdot \ddot{a}_{x_{e}+A}^{r \alpha} \cdot l_{\left(x_{e}+A, t\right)} \cdot \sum_{h=1}^{A} F^{* h} \\
& { }^{[R]} V_{t}^{c} \\
& \text { Present value of future contributions } \\
& \text { for retirement } \\
& =\underbrace{\bar{P}_{\left(x_{e}+A, t\right)} \cdot l_{\left(x_{e}+A, t\right)} \cdot \ddot{a}_{x_{e}+A}^{r \alpha} \cdot \sum_{h=1}^{A} F^{* h}}_{\text {Present value of retirement benefits }}-\overbrace{\theta^{R} \cdot\left(\sum_{k=0}^{A-1} \sum_{h=0}^{k} l_{\left(x_{e}+k, t\right)} \cdot y_{\left(x_{e}+k, t\right)} \cdot F^{* h}\right)} \\
& { }^{N D C[R]} V_{t}^{C} \\
& -\overbrace{\sum_{\sum_{k=1}^{A} K_{\left(x_{e}+k, t\right)}^{T a c(R)}}^{A}}
\end{aligned}
$$

where

$$
V \overline{S P}_{\left(x_{e}+A, t\right)}^{R} \cdot l_{\left(x_{e}+A, t\right)}=\overline{S P}_{\left(x_{e}+A, t\right)} \cdot l_{\left(x_{e}+A, t\right)} \cdot \ddot{a}_{x_{e}+A}^{r \alpha}
$$

with $F^{*}=\frac{1+G}{1+d}$ being an indexing factor dependent on $G$ (wage bill growth) and $d$ (discount rate).

For LTC:

$$
\begin{aligned}
& \left.{ }^{N C R}[L T C] V_{t}^{c}={ }^{[L T C]} V_{t}^{c}-{ }^{N D C[L T C}\right] V_{t}^{c}=V \overline{S P}_{\left(x_{e}+A, t\right)}^{L T C} \cdot l_{\left(x_{e}+A, t\right)} \cdot \sum_{h=1}^{A} F^{* h} \\
& =\left(\left(\bar{P}_{\left(x_{e}+A, t\right)}-\bar{P}_{\left(x_{e}+A, t\right)}^{N D C}\right) \cdot l_{\left(x_{e}+A, t\right)} \cdot \sum_{j=1}^{n} \xi_{r j} A_{x_{e}+A}^{r d_{j} \alpha}\right) \cdot \sum_{h=1}^{A} F^{* h} \\
& =\underbrace{\left(\bar{P}_{\left(x_{e}+A, t\right)} \cdot l_{\left(x_{e}+A, t\right)} \cdot \sum_{j=1}^{n} \xi_{r j} A_{x_{e}+A}^{r d_{j} \alpha}\right) \sum_{h=1}^{A} F^{* h}} \\
& \text { Present value of LTC benefits } \\
& \text { Present value of future contributions for LTC }
\end{aligned}
$$

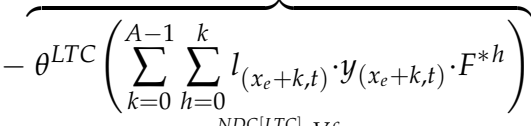

$$
\begin{aligned}
& -\overbrace{\underbrace{\sum_{k=1}^{A} K_{\left(x_{e}+k, t\right)}^{\operatorname{Tac}(\text { LTC })}}_{\text {Accumulated notional capital for LTC }}}
\end{aligned}
$$

where

$$
V \overline{S P}_{\left(x_{e}+A, t\right)}^{L T C} \cdot l_{\left(x_{e}+A, t\right)}=\overline{S P}_{\left(x_{e}+A, t\right)} \cdot l_{\left(x_{e}+A, t\right)} \cdot \sum_{j=1}^{n} \xi_{r j} A_{x_{e}+A}^{r d_{j} \alpha}
$$

Under the assumptions made, the present value of pensions for current contributors is equivalent to the sum of the present value of future contributions and the total accumulated notional capital for retirement and LTC. 
As a result, the total liabilities to contributors for retirement and LTC due to the NCRs can be expressed as:

$$
\begin{aligned}
& { }^{N C R} V_{t}^{c}=V_{t}^{c}-{ }^{N D C} V_{t}^{c}=V \overline{S P}_{\left(x_{e}+A, t\right)} \cdot l_{\left(x_{e}+A, t\right)} \cdot \sum_{h=1}^{A} F^{* h} \\
& =\left(\bar{P}_{\left(x_{e}+A, t\right)}-\bar{P}_{\left(x_{e}+A, t\right)}^{N D C}\right) \cdot l_{\left(x_{e}+A, t\right)} \cdot A F_{x_{e}+A}^{L T C(n)} \cdot \sum_{h=1}^{A} F^{* h}
\end{aligned}
$$

The system's total NCR liabilities $\left({ }^{N C R} V_{t}^{S}\right)$ are also the sum of all the liabilities described above:

$$
N C R V_{t}^{S}=\overbrace{N C R[R] V_{t}^{r}+{ }^{N C R[L T C]} V_{t}^{r}}^{\text {Pensioners }}+\underbrace{\overbrace{N C R[R] V_{t}^{c}+{ }^{N C R[L T C]} V_{t}^{c}}^{\text {Under alternative } 1 \text { is zero }}}_{\text {Contributors }}
$$

and the system's total liabilities $\left(V_{t}^{S}\right)$ are:

$$
V_{t}^{S}={ }^{N D C} V_{t}^{S}+{ }^{N C R} V_{t}^{S}
$$

\section{Appendix A.6 The Assets Side and the Steady State Balance Ratio}

The system's contribution asset $\left({ }^{N D C} C A_{t}^{S}\right)$ can be understood as the maximum level of liabilities $\left({ }^{N D C} V_{t}^{S}\right)$ that can be financed by the contribution rate.

A different question is the redistributive element of the scheme, i.e., the commitments to pensioners and contributors to cover NCR rights. In our proposal, the counterpart on the assets side is the buffer fund allocated to back up the non-contributory rights $\left({ }^{N C R} B F_{t}^{S}\right)$. that should be financed from general revenues. Therefore,

$$
\overbrace{N D C C A_{t}^{S}+{ }^{N C R} B F_{t}^{S}}^{\text {Total assets }}=\underbrace{N^{N D C} V_{t}^{S}+{ }^{N C R} V_{t}^{S}}_{\text {Total liabilities }}
$$

The value of the system's contribution asset is the product of the system's turnover duration $\left(T D_{t}^{S}\right)$ and the value of the NDC system's contributions $\left(C_{t}^{S}\right)$ made in that period for the retirement and LTC contingencies:

$$
{ }^{N D C} C A_{t}^{S}=T D_{t}^{S} \cdot C_{t}^{S}
$$

The $T D_{t}^{S}$ for the system is interpreted as the number of years expected to elapse before the committed liabilities with contributors (pay-in, $p t_{c}^{S}$ ) and pensioners (pay-out, $p t_{r}^{S}$ ) for both retirement and LTC contingencies are completely renewed at the current contribution level.

In the case of retirement, the $T D_{t}^{R}$ indicates the expected years a contribution will stay in the system if it were paid by a hypothetical contributor of $A_{c}$ years and remained within the contribution liability until retirement age was reached (pay-in, $p t_{c}^{R}=A-A_{c}$ ), after which it was received by a hypothetical able/healthy pensioner of $A_{r}^{R}$ years after remaining within the liability to this type of pensioner during the pay-out $\left(p t_{c}^{R}=A_{r}^{R}-A\right)$.

Similarly, for the LTC contingency, the $T D_{t}^{L T C}$ represents the expected years a monetary unit contributed to the system will stay in the system if it were paid by a contributor of $A_{C}$ years and remained within the liability to contributors until the affiliate became an LTC recipient (pay-in, $p t_{c}^{L T C}$ ), after which it was received by a healthy/dependent pensioner of $A_{r}^{L T C}$ years after remaining within the liability to this type of pensioner during the pay-out $\left(p t_{c}^{L T C G}\right)$.

The system's turnover duration can be calculated as the weighted average of the $T D_{t}^{S}$ for both contingencies, LTC $\left(T D_{t}^{L T C}\right)$ and retirement $\left(T D_{t}^{R}\right)$, with the weighting being the spending on pensions by contingency $\left(P T_{t}^{L T C}\right.$ and $\left.P T_{t}^{R}\right)$ as a proportion of total spending $\left(P T_{t}^{N D C}\right)$. Thus,

$$
T D_{t}^{S}=\frac{T D_{t}^{L T C} \cdot P T_{t}^{L T C}+T D_{t}^{R} \cdot P T_{t}^{R}}{P T_{t}^{N D C}}
$$

where $P T_{t}^{L T C}=\sum_{i=1}^{n} P T_{t}^{d_{i}}$ and $T D_{t}^{L T C}$ can also be calculated as the weighted average of the $n T D_{t}^{d_{i}}$, with the weighting being the spending on $i \in\{1,2, \cdots, n\}$ pensions $\left(P T_{t}^{d_{i}}\right)$ as a part of total LTC spending $\left(P T_{t}^{L T C}\right)$. Reasoning by analogy with the development made by [31,34], the system's turnover duration can also be calculated as the difference between the weighted average of the average ages of LTC $\left(A_{r}^{L T C}\right)$ and retirement 
$\left(A_{r}^{R}\right)$ pensioners, with the weightings here being spending on pensions per contingency as a proportion of total spending and the average age of the contributors $\left(A_{C}^{L T C}=A_{C}^{R}=A_{C}\right) . A_{r}^{L T C}$ is the weighted average of the $i \in\{1,2, \cdots, n\}$ grade - LTC average ages.

The analytical expression for the system's TD can also be expressed in the form of pay-out and pay-in durations:

$$
T D_{t}^{S}=\frac{\overbrace{\left(A_{r}^{L T C}-A_{c}\right)}^{\left(p t_{c}^{L T C}+p t_{r}^{L T C}\right)} \cdot P T_{t}^{L T C}+\overbrace{\left(A_{r}^{R}-A_{c}\right)}^{\left(p t_{c}^{R}+P t_{r}^{R}\right)} \cdot P T_{t}^{R}}{P T_{t}^{N D C}}
$$

Finally, the impact on the ABS of introducing the MPB is the difference between Formulas (A24) and (A15), i.e., the liabilities originating from NCRs, and this needs to have an equivalent entry on the assets side. In our proposal, there are two entries, ${ }^{N C R} B F_{t}^{L T C}$ and ${ }^{N C R} B F_{t}^{R}$, and their amounts reveal the present value of the NCRs. Thus, an NDC scheme providing an MPB becomes a hybrid type of DC system and is partially funded in this approach.

The system's buffer fund $\left({ }^{N C R} B F_{t}^{S}\right)$, which gives credibility and financial sustainability to the pensions promises made in the form of the MPB, can be computed as follows:

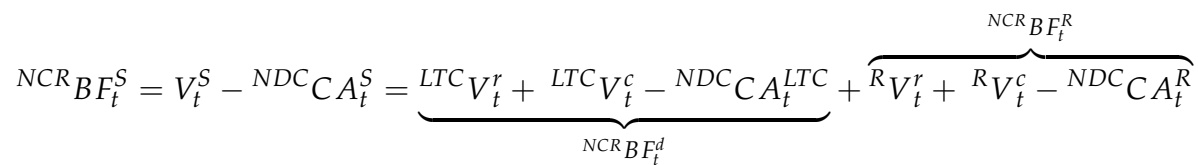

and the amount of this is the present value of the public subsidies needed to finance the MPB.

It is also straightforward to obtain that the value of the system's public contribution asset is the product of the system's turnover duration $\left(T D_{t}^{S}\right)$ and the value of the NCR public contributions $\left({ }^{N C R} S_{t}^{S}\right)$ made in that period by the sponsor to pay for the MPBs, and this is equivalent to the system's buffer fund:

$$
{ }^{N C R} C A_{t}^{S}=T D_{t}^{S} \cdot{ }^{N C R} S_{t}^{S}={ }^{N C R} B F_{t}^{S}
$$

If the approach adopted to back up the increase in liabilities due to the introduction of an MPB is the buffer fund method, then the higher the level of the MPB stipulated, the higher the degree of funding $\left(D F_{t}^{S}\right)$ needed to maintain the system's financial equilibrium (or short-term sustainability). The degree of funding is the ratio between the amount of the buffer fund and the system's total liabilities:

$$
D F_{t}^{S}=\frac{{ }^{N C R} B F_{t}^{S}}{V_{t}^{S}}
$$

The system's sustainability indicator, known as the steady state balance ratio $\left(B R_{t}^{S}\right.$, the ratio between the system's assets and liabilities), has to be equal to one in the case of a balanced pension system, our primary assumption.

Because an NDC scheme is not prefunded and uses current contribution revenues to finance current pension expenditure, it cannot promise the necessary liquidity at all times unless special arrangements are made. In practice, for the sake of liquidity, it is advisable to have a reserve fund, as pointed out by Holzmann et al. [110], who calculated that by assuming only stochastic-type fluctuations around a mean notional rate of return, the size of a liquidity reserve fund should accumulate 6-24 months of expenditure. A reserve fund is also advisable in DB PAYG pension systems. The actuarial balance of the OASDI (old age, survivors and disability insurance) program considers that the minimum level of the reserve fund is one year of expenditure.

Finally, in our model, the balance ratio can be broken down by contingencies, with the weightings here being the liabilities per contingency as a proportion of total liabilities:

$$
B R_{t}^{S}=B R_{t}^{R} \cdot \frac{\left({ }^{N D C[R]} V_{t}^{c}+{ }^{N D C[R]} V_{t}^{r}\right)}{N D C V_{t}^{S}}+B R_{t}^{L T C} \cdot \frac{\left(N D C[L T C] V_{t}^{c}+N D C[L T C] V_{t}^{r}\right)}{N D C V_{t}^{S}}
$$

As Metzger [11] pointed out, the question of sustainability, as conveyed by our methodology, has a result different to that of generational accounting (GA), which assesses the sustainability of the pension scheme in the very long term given the underlying assumptions about future demographic developments.

GA has become an important instrument for assessing the financial sustainability of the public sector. It calculates "lifetime net tax rates" for each one-year cohort of the population up to at least Age 90 and a separate lifetime net tax rate for all future generations combined [111,112]. However, it is unable to take into account the many details of a pension system [16]. GA may be an interesting academic exercise but, despite its spread worldwide, some researchers find that it suffers from numerous problems of complexity, logic and validity [113]. 
Our proposal measures sustainability via the balance ratio from a different perspective, i.e., under a mature-state assumption with respect to the year of the valuation date. If the time interval between new estimates of the solvency indicator is short enough (one year), each interval between can be interpreted as a transitory steady state [114]. This is the approach developed in practice by the Swedish authorities [10], so, at least on the practical side, the mature state assumed by this social insurance accounting framework cannot be viewed as a limitation.

\section{Appendix A.7 The Income Statement}

The change in net worth, also known as the net gain/loss for the year, is determined in the simplest way by comparing the system's assets and liabilities in two consecutive periods $(t-1, t]$.

$$
N W_{t}^{S}=\overbrace{\underbrace{\delta B F_{t}^{S}}_{\text {Fund asset }}+\underbrace{\delta C A_{t}^{S}}_{\text {Contribution asset }}-\overbrace{\delta V_{t}^{S}}^{\text {Changes }}}^{\text {Liabilities }}
$$

If $N W_{t}^{S}>0 \Rightarrow P_{t}^{S}$, the change in net worth is positive, i.e., in this period, the system has actuarial gains. If $N W_{t}^{S}<0 \Rightarrow L_{t}^{S}$, the change in net worth is negative, i.e., in this period, the system has losses. If $N W_{t}^{S}=0$, the system's worth (financial position) does not change.

The net gain/loss for the year can be detailed as follows:

1 Change in fund/financial asset

$$
\delta B F_{t}^{S}=C_{t}^{S}-P T_{t}^{S}+r_{t} \cdot B F_{t-1}^{S}
$$

where

$C_{t}^{S}$ :is the total income from contributions.

$P T_{t}^{S}$ is the total pension disbursements. $r_{t}$ is the net return on funded capital.

2 Change in contribution asset:

$$
\begin{gathered}
\delta C A_{t}^{S}=C A_{t}^{S}-C A_{t-1}^{S}=\overbrace{\delta C_{t}^{S}}^{\text {Revenue effect }}+\underbrace{\delta T D_{t}^{S}}_{\begin{array}{c}
\text { Turnover duration } \\
\text { effect }
\end{array}} \\
=\overbrace{\left(\left(C_{t}^{S}-C_{t-1}^{S}\right) \cdot \frac{\left(T D_{t-1}^{S}+T D_{t}^{S}\right)}{2}\right)}^{\delta C_{t}^{S}}+(\underbrace{\frac{\left(C_{t}^{S}+C_{t-1}^{S}\right)}{2} \cdot\left(T D_{t}^{S}-T D_{t-1}^{S}\right)}_{\delta T D_{t}^{S}})
\end{gathered}
$$

Formula (A35) resembles the formula used by the Swedish authorities [10], but there are many ways to analyze the change in contribution asset including the following:

$$
\delta C A_{t}^{S}=\overbrace{\left(C_{t}^{S}-C_{t-1}^{S}\right) \cdot T D_{t-1}^{S}}^{\delta C_{t}^{S}}+\underbrace{C_{t}^{S} \cdot\left(T D_{t}^{S}-T D_{t-1}^{S}\right)}_{\delta T D_{t}^{S}}
$$

3 Change in pension liability:

$$
\delta V_{t}^{S}=V_{t}^{S}-V_{t-1}^{S}=C_{t}^{S}-P T_{t}^{S}+I_{t}^{S}+e_{t}^{S}+B_{t}^{S}
$$

where

$I_{t}^{S}$ is the indexation effect.

$e_{t}^{S}$ is the life expectancy effect.

$B_{t}^{S}$ is the biometric data effect.

Finally, the income statement can easily be disaggregated by contingency in Formulas (A33)-(A37) by changing the superscript " $S$ " to " $R$ " or "LTC" where necessary. 


\section{References}

1. Britton, A. What is accounting? In The Routledge Companion to Accounting, Reporting and Regulation; Van Mourik, C., Walton, P., Eds.; Routledge: Abingdon, UK, 2014; Chapter 1; pp. 3-33. ISBN 978-0-415-62573-9.

2. OECD; IFAC. Accrual Practices and Reform Experiences in OECD Countries; OECD Publishing: Paris, France, 2017; ISBN 978-92-64-27057-2.

3. Hoogervorst, H. The Imprecise World of Accounting. Speech Given at the International Association for Accounting Education \& Research (IAAER) Conference in Amsterdam. June 2012. Available online: http:/ / archive.ifrs.org/ Alerts/Conference/Pages/HH-speech-Amsterdam-June-2012.aspx (accessed on 8 January 2018).

4. OSFIC. Measuring the Financial Sustainability of the Canada Pension Plan (Actuarial Study, No. 10); Ottawa, Office of the Superintendent of Financial Institutions Canada-Office of the Chief Actuary, 2012. Available online: http:/ / www.osfi-bsif.gc.ca/Eng/Docs/cppas10.pdf (accessed on 7 August 2018).

5. OSFIC. Twenty-Sixth Actuarial Report on the Canada Pension Plan as at 31 December 2012; Ottawa, Office of the Superintendent of Financial Institutions Canada-Office of the Chief Actuary, 2013. Available online: http:/ / www.actuarialsolutionsinc.com/wp-content/uploads/2017/11/December-31-2012-Office-of-theSuperintendent-of-Financial-Institutions-Canada-Actuarial-Report-26th-on-the-Canada-Pension-Plan. pdf (accessed on 7 August 2018).

6. OSFIC. Assessing the Sustainability of the Canada Pension Plan through Actuarial Balance Sheets (Actuarial study, No. 13); Ottawa, Office of the Superintendent of Financial Institutions Canada-Office of the Chief Actuary, 2014. Available online: http://www.osfi-bsif.gc.ca/Eng/Docs/ascpp.pdf (accessed on 7 August 2018).

7. Board of Trustees. Federal Old-Age and Survivors Insurance and Disability Insurance Trust Funds (BOT); 2017 Annual Report; Government Printing Office: Washington, DC, USA, 2017.

8. AAD (Actuarial Affairs Division). Summaries of the 2014 Actuarial Valuation and Reform Options; Pension Bureau, Ministry of Health, Labour, and Welfare: Tokyo, Japan, 2017.

9. GAD (Government Actuary's Department). Government Actuary's Quinquennial Review of the National Insurance Fund as at April 2015; Government Actuary's Department: London, UK, 2017; ISBN 978-1-5286-0083-5.

10. The Swedish Pension System (TSPS). Orange Annual Report 2016; Settergren, O., Birkholz, K., Eds.; Swedish Pensions Agency (Pensionsmyndigheten): Stockholm, Sweden, 2017.

11. Metzger, C. An actuarial balance sheet of the Swiss old-age pension scheme. Int. Soc. Secur. Rev. 2018, 71, 25-49. [CrossRef]

12. SNA. System of National Accounts 2008; The European Commission, The International Monetary Fund, The Organization for Economic Co-operation and Development (OECD), The United Nations and the World Bank: New York, NY, USA, 2009; ISBN 978-92-1-161522-7.

13. EUROSTAT. European System of Accounts. ESA 2010; Publications Office of the European Union: Luxembourg, 2013; ISBN 978-92-79-31242-7. [CrossRef]

14. Keuning, S. Introduction. In ECB/Eurostat Workshop on Pensions, Frankfurt, Germany, 2009 29-30 April; Mink, R., Rodriguez Vives, M., Eds.; European Central Bank: Frankfurt am Main, Germany, 2010; pp. 7-10. ISBN 978-92-899-0623-4.

15. EUROSTAT; European Central Bank. Technical Compilation Guide for Pension Data in National Accounts; Eurostat Methodologies \& Working papers; Publications Office of the European Union: Luxembourg, 2011; ISBN 978-92-79-22515-4. [CrossRef]

16. Holzmann, R.; Palacios, R.; Zviniene, A. On the economics and scope of implicit pension debt: An international perspective. Empirica 2001, 28, 97-129. [CrossRef]

17. Kaier, K.; Müller, C. New figures on unfunded public pensions entitlements across Europe: Concept, results and applications. Empirica 2015, 42, 865-895. [CrossRef]

18. Wendorff, K. The use of pension data for policy making. In ECB/Eurostat Workshop on Pensions, Frankfurt, Germany, 2009 29-30 April; Mink, R., Rodriguez Vives, M., Eds.; European Central Bank: Frankfurt am Main, Germany, 2010; pp. 129-135. ISBN 978-92-899-0623-4.

19. Plamondon, P.; Drouin, A.; Binet, G.; Cichon, M.; McGillivray, W.R.; Bédard, M.; Pérez-Montas, H. Actuarial Practice in Social Security; Quantitative methods in social protection series; International Labour Office/International Social Security Association: Geneva, Switzerland, 2002; ISBN 92-2-110863-5. 
20. Settergren, O. Financial and Inter-Generational Balance? An Introduction to How the Swedish Pension System Manages Conflicting Ambitions. Scand. Insur. Q. 2003, 2, 99-114.

21. Takayama, N. The Balance Sheet of Social Security Pensions in Japan; Discussion Paper 235; Center for Intergenerational Studies, Institute of Economic Research, Hitotsubashi University: Tokyo, Japan, 2004.

22. Settergren, O.; Mikula, B.D. The rate of return of pay-as-you-go pension systems: A more exact consumptionloan model of interest. J. Pension Econ. Financ. 2005, 4, 115-138. [CrossRef]

23. Settergren, O.; Mikula, B.D. Actuarial Accounting: Calculating Intergenerationally Fair and Sustainable Life-Cycle Contribution Rates. In Mainstreaming Aging; Marin, B., Zaidi, A., Eds.; European Center Vienna, Ashgate: Farnham, UK, 2007; ISBN 978-0-7546-7361-3.

24. Boado-Penas, M.C.; Valdés-Prieto, S.; Vidal-Meliá, C. An Actuarial Balance Sheet for Pay-As-You-Go Finance: Solvency Indicators for Spain and Sweden. Fisc. Stud. 2008, 29, 89-134. [CrossRef]

25. Rashbrooke, G. Exploration of application of actuarial Accounting methodology to the New Zealand flat rate social security pension. In Proceedings of the Joint Colloquium of the IACA, PBSS and IAAHS Sections, Boston, MA, USA, 4-7 May 2008.

26. Boado-Penas, M.C.; Settergren, O.; Vidal-Meliá, C. El Balance actuarial del Sistema de reparto. Modelo "Sueco" frente a modelo "EE.UU.": Posible aplicación al caso español. Span. J. Financ. Account. 2011, 97-123. [CrossRef]

27. Settergren, O. A Decade of Actuarial Accounting for the NDC Scheme in Sweden: Quantifying Change in the Financial Position of a PAYG Pension Plan. In NDC Pension Schemes in a Changing Pension World; Holzmann, R., Palmer, E., Robalino, D., Eds.; World Bank: Washington, DC, USA, 2013; Chapter 21; Volume 2, ISBN 978-0-8213-9479-3. [CrossRef]

28. Boado-Penas, M.C.; Vidal-Meliá, C. The Actuarial Balance of the Pay-As-You-Go Pension System: The Swedish NDC model versus the US DB model. In NDC Pension Schemes in a Changing Pension World; Holzmann, R., Palmer, E., Robalino, D., Eds.; World Bank: Washington, DC, USA, 2013; Chapter 14; Volume 2, ISBN 978-0-8213-9479-3. [CrossRef]

29. Vidal-Meliá, C.; Boado-Penas, M.C. Compiling the actuarial balance for pay-as-you-go pension systems. Is it better to use the hidden asset or the contribution asset? Appl. Econ. 2013, 45, 1303-1320. [CrossRef]

30. Billig, A.; Ménard, J.C. Actuarial balance sheets as a tool to assess the sustainability of social security pension systems. Int. Soc. Secur. Rev. 2013, 66, 31-62. [CrossRef]

31. Ventura-Marco, M.; Vidal-Meliá, C. An Actuarial Balance Sheet Model for Defined Benefit Pay-As-You-Go Pension Systems with Disability and Retirement Contingencies. Astin Bull. 2014, 44, 367-415. [CrossRef]

32. Vidal-Meliá, C. An assessment of the 2011 Spanish pension reform using the Swedish system as a benchmark. J. Pension Econ. Financ. 2014, 13, 297-333. [CrossRef]

33. Metzger, C.; The German Statutory Pension Scheme: Balance Sheet, Cross-Sectional Internal Rates of Return and Implicit Tax Rates. Discussion Papers, Forschungszentrum Generationenverträge der Albert-Ludwigs-Universität Freiburg, No. 63, Albert-Ludwigs-Universität Freiburg, Forschungszentrum Generationenverträge (FZG), Freiburg i. Br., 2016. Available online: http:/ /www.fiwi1.uni-freiburg.de/ publikationen/373.pdf (accessed on 7 August 2018).

34. Pérez-Salamero González, J.M.; Ventura-Marco, M.; Vidal-Meliá, C. A 'Swedish' Actuarial Balance Sheet for a Notional Defined Contribution Pension Scheme with Disability and Minimum Pension Benefits. Int. Soc. Secur. Rev. 2017, 70, 79-104. [CrossRef]

35. Vidal-Meliá, C.; Ventura-Marco, M.; Pla-Porcel, J. An NDC approach to helping pensioners cope with the cost of long-term care. J. Pension Econ. Financ. 2018, 1-29. [CrossRef]

36. Christopherson, D.L. A new idea for insuring long-term care. J. Am. Soc. CLU ChFC 1992, 46, 42-53.

37. Scanlon, W.J. Possible Reforms for Financing Long-Term Care. J. Econ. Perspect. 1992, 6, 43-58. [CrossRef] [PubMed]

38. Nuttall, S.R.; Blackwood, R.J.L.; Bussell, B.M.H.; Cliff, J.P.; Cornall, M.J.; Cowley, A.; Gatenby, P.L.; Webber, J.M. Financing Long-Term Care in Great Britain. J. Inst. Actuar. 1994, 121, 1-68. [CrossRef]

39. Chen, Y.P. Funding Long-term Care in the United States: The Role of Private Insurance. Geneva Pap. Risk Insur. Issues Pract. 2001, 26, 656-666. [CrossRef]

40. Pitacco, E. LTC insurance in Italy. In Proceedings of the XXVII ICA-Cancun, 2002 Health Seminar on Critical Issues in Managing Long-Term Care Insurance, Cancun, Mexico, 17-19 March 2002. 
41. Getzen, T.E. Long life insurance: A prototype for funding long-term care. Health Care Financ. Rev. 1998, 10, $47-56$.

42. Murtaugh, C.; Spillman, B.; Warshawsky, M. In Sickness and in Health: An Annuity Approach to Financing Long-Term Care and Retirement Income. J. Risk Insur. 2001, 68, 225-254. [CrossRef]

43. Spillman, B.; Murtaugh, C.; Warshawsky, M. Policy implications of an annuity approach to integrating long-term care financing and retirement income. J. Aging Health 2003, 15, 45-73. [CrossRef] [PubMed]

44. Yakoboski, P.J. Understanding the motivations of long-term care insurance owners: The importance of retirement planning. Benefits Q. (Second Quart.) 2002, 18, 16-21.

45. Turner, J.A.; Hughes, G.; Chłoń-Domińczak, A.; Rajnes, D.M. Improving Pension Income and Reducing Poverty at Advanced Older Ages: Longevity Insurance Benefits in Ireland and Poland as Models for the United States. J. Retire. 2017, 4, 111-120. [CrossRef]

46. Kenny, T.; Barnfield, J.; Daly, L.; Dunn, A.; Passey, D.; Rickayzen, B.; Teow, A. The future of social care funding: Who pays? Br. Actuar. J. 2017, 22, 10-44. [CrossRef]

47. Valdés-Prieto, S. The Financial Stability of Notional Account Pensions. Scand. J. Econ. 2000, 102, $395-417$. [CrossRef]

48. Barr, N. Non-financial defined contribution pensions: Mapping the Terrain. In Pension Reform: Issues and Prospects for Notional Defined Contribution (NDC) Schemes; Holzmann, R., Palmer, E., Eds.; World Bank: Washington, DC, USA, 2006; Chapter 4.

49. Holzmann, R. The ABCs of Nonfinancial Defined Contribution (NDC) Schemes. Int. Soc. Secur. Rev. 2017, 70, 53-77. [CrossRef]

50. Colombo, F.; Mercier, J. Help Wanted? Fair and Sustainable Financing of Long-Term Care Services. Appl. Econ. Perspect. Policy 2012, 34, 316-332. [CrossRef]

51. De la Maisonneuve, C.; Oliveira Martins, J. Public Spending on Health and Long-term Care: A new set of projections. In OECD Economic Policy Papers; No. 6; OECD Publishing: Paris, France, 2013.

52. Swartz, K. Searching for a Balance of Responsibilities: OECD Countries' Changing Elderly Assistance Policies. Annu. Rev. Public Health 2013, 34, 397-412. [CrossRef] [PubMed]

53. Worrall, P.; Chaussalet, T. A structured review of long-term care demand modelling. Health Care Manag. Rev. 2015, 18, 173-194. [CrossRef] [PubMed]

54. Costa-Font, J.; Courbage, C.; Zweifel, P. Policy dilemmas in financing long-term care in Europe. Glob. Policy 2017, 8 (Suppl. S2), 38-45. [CrossRef]

55. Da Roit, B.; Le Bihan, B.; Österle, A. Cash-for-care benefits. In Long-Term Care Reforms in OECD Countries; Fernandez, J.L., Gori, C., Wittenberg, R., Eds.; Policy Press: Bristol, UK, 2016; Chapter 7; pp. 143-166. ISBN 9781447305057.

56. Damiani, G.; Farelli, V.; Anselmi, A.; Sicuro, L.; Solipaca, A.; Burgio, A.; Domenica, F.I.; Ricciardi, W. Patterns of Long Term Care in 29 European countries: Evidence from an exploratory study. BMC Health Serv. Res. 2011, 11, 316. [CrossRef] [PubMed]

57. Haberman, S.; Pitacco, E. Actuarial Models for Disability Insurance; Chapman and Hall/CRC: London, UK, 1999; ISBN 9780849303890.

58. Rickayzen, B. An analysis of disability-linked annuities. In Actuarial Research Paper; No. 180; Cass Business School: London, UK, 2007; ISBN 978-1-905752-09-6.

59. Warshawsky, M.J. Retirement Income: Risks and Strategies; MIT Press: Cambridge, MA, USA, 2012; ISBN 9780262525121.

60. Brown, J.; Warshawsky, M. The life care annuity: A new empirical examination of an insurance innovation that addresses problems in the markets for life annuities and long-term care insurance. J. Risk Insur. 2013, 80, 677-703. [CrossRef]

61. Pitacco, E. Health Insurance. Basic Actuarial Models; EAA Series; Springer: Berlin/Heidelberg, Germany, 2014. [CrossRef]

62. Pla-Porcel, J.; Ventura-Marco, M.; Vidal-Meliá, C. Life Care Annuities (LCA) Embedded in a Notional Defined Contribution (NDC) Framework. Astin Bull. 2016, 46, 331-363. [CrossRef]

63. Holzmann, R.; Palmer, E. (Eds.) Pension Reform: Issues and Prospects for Notional Defined Contribution (NDC) Schemes; World Bank: Washington, DC, USA, 2006. [CrossRef]

64. Barr, N.; Diamond, P. Pension Reform: A Short Guide; Oxford University Press: New York, NY, USA, 2009; ISBN 13 9780195387728. [CrossRef] 
65. Chłon-Domińczak, A.; Strzelecki, P. The minimum pension as an instrument of poverty protection in the defined contribution pension system-An example of Poland. J. Pension Econ. Financ. 2013, 12, 326-350. [CrossRef]

66. Hagemejer, K.; Woodall, J. How should the adequacy of pension coverage be balanced against financial sustainability? Aust. J. Actuar. Pract. 2014, 2, 21-31.

67. Boado-Penas, M.C.; Vidal-Meliá, C. Nonfinancial defined contribution pension schemes: Is a survivor dividend necessary to make the system balanced? Appl. Econ. Lett. 2014, 21, 242-247. [CrossRef]

68. Arnold-Gaille, S.; Boado-Penas, M.C.; Godinez-Olivares, H. Longevity Risk in Notional Defined Contribution Pension Schemes: A Solution. Geneva Pap. Risk Insur. Issues Pract. 2016, 41, 24-52. [CrossRef]

69. Vidal-Meliá, C.; Boado-Penas, M.C.; Navarro-Cabo, F. Notional defined contribution pension schemes: Why does only Sweden distribute the survivor dividend? J. Econ. Policy Reform. 2016, 19, 200-220. [CrossRef]

70. Knell, M. Increasing life expectancy and NDC pension systems. J. Pension Econ. Financ. 2018, 17, 170-199. [CrossRef]

71. IPSASB. Recognition and Measurement of Social Benefits. Consultation Paper, International Public Sector Accounting Standards Board, International Federation of Accountants (IFAC). July 2015. Available online: https:/ / www.ifac.org/publications-resources/recognition-and-measurement-social-benefits (accessed on 7 August 2018).

72. Chen, G.; Matkin, D.S. Actuarial inputs and the valuation of public pension liabilities and contribution requirements: A simulation approach. Public Budg. Financ. 2017, 37, 68-87. [CrossRef]

73. Gronchi, S.; Nisticò, S. Theoretical Foundations of Pay-as-You-Go Defined-Contribution Pension Schemes. Metroeconomica 2008, 59, 131-159. [CrossRef]

74. Biggs, A.G. Public Sector Pensions: How Well Funded Are They, Really? State Budget Solutions; American Enterprise Institute: Washington, DC, USA, 2012.

75. Andonov, A.; Bauer, R.; Cremers, M. Pension Fund Asset Allocation and Liability Discount Rates. 2017. Available online: https:/ / ssrn.com/abstract=2070054 (accessed on 7 August 2018).

76. Brown, J.; Pennacchi, G. Discounting pension liabilities: Funding versus value. J. Pension Econ. Financ. 2016, 15, 254-284. [CrossRef]

77. Ventura-Marco, M.; Vidal-Meliá, C. Integrating retirement and permanent disability in NDC pension schemes. Appl. Econ. 2016, 48, 1081-1102. [CrossRef]

78. Stallard, E. Compression of Morbidity and Mortality: New Perspectives. N. Am. Actuar. J. 2016, 20, 341-354. [CrossRef] [PubMed]

79. Kreft, D.; Doblhammer, G. Expansion or compression of long-term care in Germany between 2001 and 2009 ? A small-area decomposition study based on administrative health data. Popul. Health Metr. 2016, 14, 1-15. [CrossRef] [PubMed]

80. Gonçalves, A.; Adami, F.; Ferreira, J.; Lebrão, M.L. Expansion of morbidity: Trends in healthy life expectancy of the elderly population, Services on Demand. Rev. Assoc. Med. Bras. 2014, 60, 434-441. [CrossRef]

81. Solé-Auró, A.; Alcañiz, M. Are we living longer but less healthy? Trends in mortality and morbidity in Catalonia (Spain), 1994-2011. Eur. J. Ageing 2015, 12, 61-70. [CrossRef] [PubMed]

82. Manton, K.G. Changing concepts of morbidity and mortality in the elderly population. Milbank Q. 1982, 60, 183-244. [CrossRef]

83. Graham, P.; Blakely, T.; Davis, P.; Sporle, A.; Pearce, N. Compression, expansion, or dynamic equilibrium? The evolution of health expectancy in New Zealand. J. Epidemiol. Community Health 2004, 58, 659-666. [CrossRef] [PubMed]

84. Robinson, J. A Long-Term Care Status Transition Model. In The Old-Age Crisis-Actuarial Opportunities: The 1996 Bowles Symposium; Georgia State University: Atlanta, GA, USA, 1996; pp. 72-79.

85. Hariyanto, E.; Dickson, D.; Pitt, G.W. Estimation of Disability Transition Probabilities in Australia I: Preliminary. Ann. Actuar. Sci. 2014, 8, 131-155. [CrossRef]

86. Hariyanto, E.; Dickson, D.; Pitt, G.W. Estimation of Disability Transition Probabilities in Australia II: Implementation. Ann. Actuar. Sci. 2014, 8, 156-175. [CrossRef]

87. Fong, J.H.; Shao, A.W.; Sherris, M. Multistate Actuarial Models of Functional Disability. N. Am. Actuar. J. 2015, 19, 41-59. [CrossRef]

88. Ai, J.; Brockett, P.L.; Golden, L.; Zhu, W. Health State Transitions and Longevity Effects on Retirees' Optimal Annuitization. J. Risk Insur. 2017, 84, 319-343. [CrossRef] 
89. Vidal-Meliá, C.; Boado-Penas, M.C.; Settergren, O. Automatic balance mechanisms in pay-as-you-go pension systems. Geneva Pap. Risk Insur. Issues Pract. 2009, 34, 287-317. [CrossRef]

90. Vidal-Meliá, C.; Boado-Penas, M.C.; Settergren, O. Instruments for improving the equity, transparency and solvency of PAYG pension systems. NDCs, ABs and ABMs. In Pension Fund Risk Management. Financial and Actuarial Modelling; Micocci, M., Gregoriou, G.N., Masala, G.B., Eds.; Chapman and Hall: New York, NY, USA, 2010; Chapter 18; pp. 419-473. ISBN 1439817520.

91. Alonso-García, J.; Boado-Penas, M.C.; Devolder, P. Automatic balancing mechanisms for notional defined contribution accounts in the presence of uncertainty. Scand. Actuar. J. 2018, 2018, 85-108. [CrossRef]

92. Börsch-Supan, A. Rational Pension Reform. Geneva Pap. Risk Insur. Issues Pract. 2007, 32, 430-446. [CrossRef]

93. Ma, C.M.; An Actuarial Balance Sheet Approach to Assessing Sustainability of Target Benefit Plans. Canadian Institute of Actuaries. Document 217045. 2017. Available online: https://www.cia-ica.ca/docs/defaultsource/2017/217045.pdf (accessed on 7 August 2018).

94. Friedberg, L.; Hou, W.; Sun, W.; Webb, A.; Li, Z. New Evidence on the Risk of Requiring Long-Term Care; Working Paper 2014-12; Center for Retirement Research at Boston College: Chestnut Hill, MA, USA, 2014.

95. Lundberg, K.; Mikula, D.; Settergren, O. Distribution of Surpluses, and the Role of Bookkeeping in the Swedish Public Pay-As-You-Go Pension Scheme. Presented at the 2nd PBSS Colloquium, Helsinki, Finland, 21-23 May 2007.

96. Munnell, A. Social Security's Financial Outlook: The 2017 Update in Perspective; Brief, 17-13; Center for Retirement Research at Boston College: Chestnut Hill, MA, USA, 2017.

97. Martell, C.R.; Kioko, S.N.; Moldogaziev, T. Impact of unfunded pension obligations on credit quality of State governments. Public Budg. Financ. 2013, 33, 24-54. [CrossRef]

98. Woodall, J.; Hagemejer, K. Maintaining Pension Levels in PAYG Schemes in Ageing Societies: Rules versus Discretion. Presented at the Technical Seminar on Pensions, International Social Security Association, Paris, France, 1-2 October 2009.

99. The Swedish Pension System (Ed.) Orange Annual Report 2008; Annika Sundén, Swedish Pensions Agency (Pensionsmyndigheten): Stockholm, Sweden, 2009.

100. Arthur, W.B.; McNicoll, G. Samuelson, population and intergenerational transfers. Int. Econ. Rev. 1978, 19, 241-246. [CrossRef]

101. Lee, R. Age structure, intergenerational transfers and economic growth: An overview. Rev. Econ. 1980, 30, 1129-1156. [CrossRef]

102. Lee, R. The formal demography of population aging, transfers, and the economic life cycle. In Demography of Aging; Martin, L.G., Preston, S.H., Eds.; National Academy Press: Washington, DC, USA, 1994; pp. 8-49.

103. Lee, R. Population, age structure, intergenerational transfers, and wealth: A new approach, with applications to the United States. J. Hum. Resour. 1994, 29, 1027-1063. [CrossRef]

104. Willis, R. Life cycles, institutions and population growth: A theory of the equilibrium interest rate in an overlapping-generations model. In Economics of Changing Age Distributions in Developed Countries; Lee, R.D., Arthur, W.B., Rodgers, G., Eds.; Clarendon Press: Oxford, UK, 1988; pp. 106-138. ISBN 13 978-0198288879.

105. Samuelson, P. An Exact Consumption Loan Model of Interest with or without the Social Contrivance of Money. J. Polit. Econ. 1958, 66, 467-482. [CrossRef]

106. United Nations Population Division (UNPD). National Transfer Accounts Manual: Measuring and Analysing the Generational Economy; United Nations: New York, NY, USA, 2013.

107. Sangster, A. The genesis of double entry bookkeeping. Account. Rev. 2016, 91, 299-315. [CrossRef]

108. Hartley, W.C.F. An Introduction to Business Accounting for Managers, 4th ed.; Pergamon Press: Oxford, UK, 1987; ISBN 978-0-08-034788-2.

109. Pla-Porcel, J.; Ventura-Marco, M.; Vidal-Meliá, C. Converting retirement benefit into a life care annuity with graded benefits. Scand. Actuar. J. 2017, 10, 829-853. [CrossRef]

110. Holzmann, R.; Palmer, E.; Robalino, D. The Economics of Reserve Funds in NDC Schemes: Role, Means, and Size to Manage Shocks. In NDC Pension Schemes in a Changing Pension World; Holzmann, R.; Palmer, E.; Robalino, D. World Bank: Washington, DC, USA, 2013; Chapter 22; Volume 2, ISBN 978-0-8213-9479-3. [CrossRef]

111. Auerbach, A.J.; Gokhale, J.; Kotlikoff, L. Generational Accounting: A New Approach to Understanding the Effects of Fiscal Policy on Saving. Scand. J. Econ. 1992, 94, 303-318. [CrossRef] 
112. Kotlikoff, L.; Raffelhüschen, B. Generational Accounting around the Globe. Am. Econ. Rev. Pap. Proc. 1999, 89, 161-166. [CrossRef]

113. Ruffing, K.A.; Van de Water, P.N.; Kogan, R. Generational Accounting Is Complex, Confusing, and Uninformative; Center on Budget and Policy Priorities (CBPP): Washington, DC, USA, 2014.

114. Lee, R. Discussion of "The Rate of Return of Pay-As-You-Go Pension Systems: A More Exact ConsumptionLoan Model of Interest". In Pension Reform: Issues and Prospects for Notional Defined Contribution (NDC) Schemes; Holzmann, R., Palmer, E., Eds.; World Bank: Washington, DC, USA, 2006.

(C) 2018 by the authors. Licensee MDPI, Basel, Switzerland. This article is an open access article distributed under the terms and conditions of the Creative Commons Attribution (CC BY) license (http:/ / creativecommons.org/licenses/by/4.0/). 